\title{
Geoelektrisk Kortlægning af Limfjordsengene ved Vester Hasing
}

Geokemiske og geofysiske forhold ved kontrolboringerne

\author{
Af \\ Birthe Dinesen \\ English Summary: \\ Geoelectrical Survey \\ of the Limfjord Area at \\ Vester Hasing \\ Geochemical and Geophysical \\ Properties at \\ the Exploration Wells
}

I kommission hos

C. A. REITZELS FORLAG (JøRGEN SANDAL)

KØBENHAVN 1962 
Med 3 tavler

With 3 plates 


\section{Geoelektrisk Kortlægning af Limfjordsengene ved Vester Hasing}

Geokemiske og geofysiske forhold ved kontrolboringerne Af

Birthe Dinesen

English Summary:

Geoelektrical Survey of the Limfjord Area at

Vester Hasing Geochemical and Geophysical Properties at the Exploration Wells 
Med 3 tavler

With 3 plates 


\section{FORORD}

Siden 1953 har geoelektrisk prospektering i stigende grad været anvendt i Danmark som hjælpemiddel ved lokalisering af vandførende lag. Desuden er der udført en del undersøgelser, hvor formålet har været at lokalisere teknisk udnyttelige ler- eller grusforekomster.

De praktiske resultater, som er opnået, har vist, at metoden er anvendelig med de begrænsninger, der følger af de danske istidsaflejringers heterogene geologiske og hydrologiske forhold.

Det foreliggende arbejde er et forsøg på at belyse nogle af de problemer, der er forbundet med tolkning af geoelektriske måleresultater. Materialet er tilvejebragt ved et geoelektrisk-geologisk undersøgelsesprojekt, der udførtes for aktieselskabet Aalborg Portland-Cement-Fabrik af Danmarks GeoloGISKE UNDERSøGELSE i årene 1956-57.

For tilladelse til at publicere de her forelagte resultater takker jeg aktieselskabet Aalborg Portland-Cement-Fabrik.

Den geoelektriske og geohydrologiske problemstilling har jeg haft lejlighed til at diskutere med professor, dr. phil. Th. Sorgenfrei, der har forestået undersøgelsesprojektet. Med statsgeolog Wr. CHRISTEnSEN og med cand. mag. N. V. JESSEN har jeg endvidere drøftet forskellige videnskabelige og praktiske spørgsmål.

Laboratorieassistent V. KROGH har medvirket ved beskrivelse af boreprøverne, og mag. scient. L. BANKE RASMUSSEN har foretaget bestemmelser af makrofossilerne. Landbrugskandidat K. Skousbøll HANSEN har udført et flertal af vandanalyserne. Tegnearbejdet er udført af fru R. BoRG.

Alle, der på forskellig måde har ydet hjælp under arbejdets udførelse, bedes modtage min tak.

Birthe Dinesen 


\section{INDHOLD}

Abstract. . . . . . . . . . . . . . . . . . 7

Indledning. . . . . . . . . . . . . . . . . . . . . . . . . 9

Den geoelektriske kortlægnings metodik. . . . . . . . . . . . . . . . . 9

Undersøgelsen i Limfjordsengene . . . . . . . . . . . . . . . . . . . . . . 9

Laboratorieundersøgelser . . . . . . . . . . . . . . . . . . . . . . . 11

Undersøgelse af boreprøver . . . . . . . . . . . . . . . . . . . 11

Kalkindhold . . . . . . . . . . . . . . . . 11

Saltholdighed . . . . . . . . . . . . . . . . . . . . . 11

Specifik elektrisk modstand. . . . . . . . . . . . . . . . . . . 12

Bestemmelsernes usikkerhed . . . . . . . . . . . . . . . 12

Vandanalyser . . . . . . . . . . . . . . . . . . . . 14

Sedimenterne . . . . . . . . . . . . . . . . . . . 15

Prøvebeskrivelser . . . . . . . . . . . . . . . . . 15

Kalkindhold . . . . . . . . . . . . . . . . . . . . . . . . 28

Saltholdighed . . . . . . . . . . . . . . . . . . . . 28

Opslæmningernes specifike modstand . . . . . . . . . . . . . . . . 30

Undersøgelsesresultaternes relation til områdets geologi . . . . . . . . . . 36

Grundvandet. . . . . . . . . . . . . . . . . . . . . 41

Vandprøvernes kemiske sammensætning . . . . . . . . . . . . . 41

Områdets hydrologiske forhold . . . . . . . . . . . . . . . . . . . 45

Den geoelektriske kortlægning . . . . . . . . . . . . . . . . . . . . . 47

Jordarternes elektriske modstand . . . . . . . . . . . . . . . . . . 47

Lerlagenes modstand . . . . . . . . . . . . . . . . . . . . . . 47

Sandlagenes modstand. . . . . . . . . . . . . . . . . . . . 48

Punktprofilerne . . . . . . . . . . . . . . . . . . . . 52

Sammenfattende vurdering af den geoelektriske kortlægning . . . . . . . 55

Summary .. . . . . . . . . . . . . . . 56 56

Litteratur . . . . . . . . . . . . . . . . . . . . 63 


\begin{abstract}
The present publication deals with a combined geoelectrical and geohydrological survey in the Limfjord area east of Aalborg, Denmark.

The geology and hydrology of the area is described. The area is characterized by its variety of the geohydrological conditions. The sediments are mainly of Quaternary age. The ground water comprise both fresh and saline waters, the salinity being due to salt water intrusion from the Limfjord, and probably occurrences of connate water of Pleistocene and Holocene age.

Some general conclusions concerning resistivity of the clay and sand deposits are drawn on the basis of determinations of salinity and conductivity of suspensions of rock samples from drilled wells and of solutions corresponding to some of the water analyses.

Finally the geoelectrical field measurements are discussed and compared with the laboratory results.
\end{abstract}




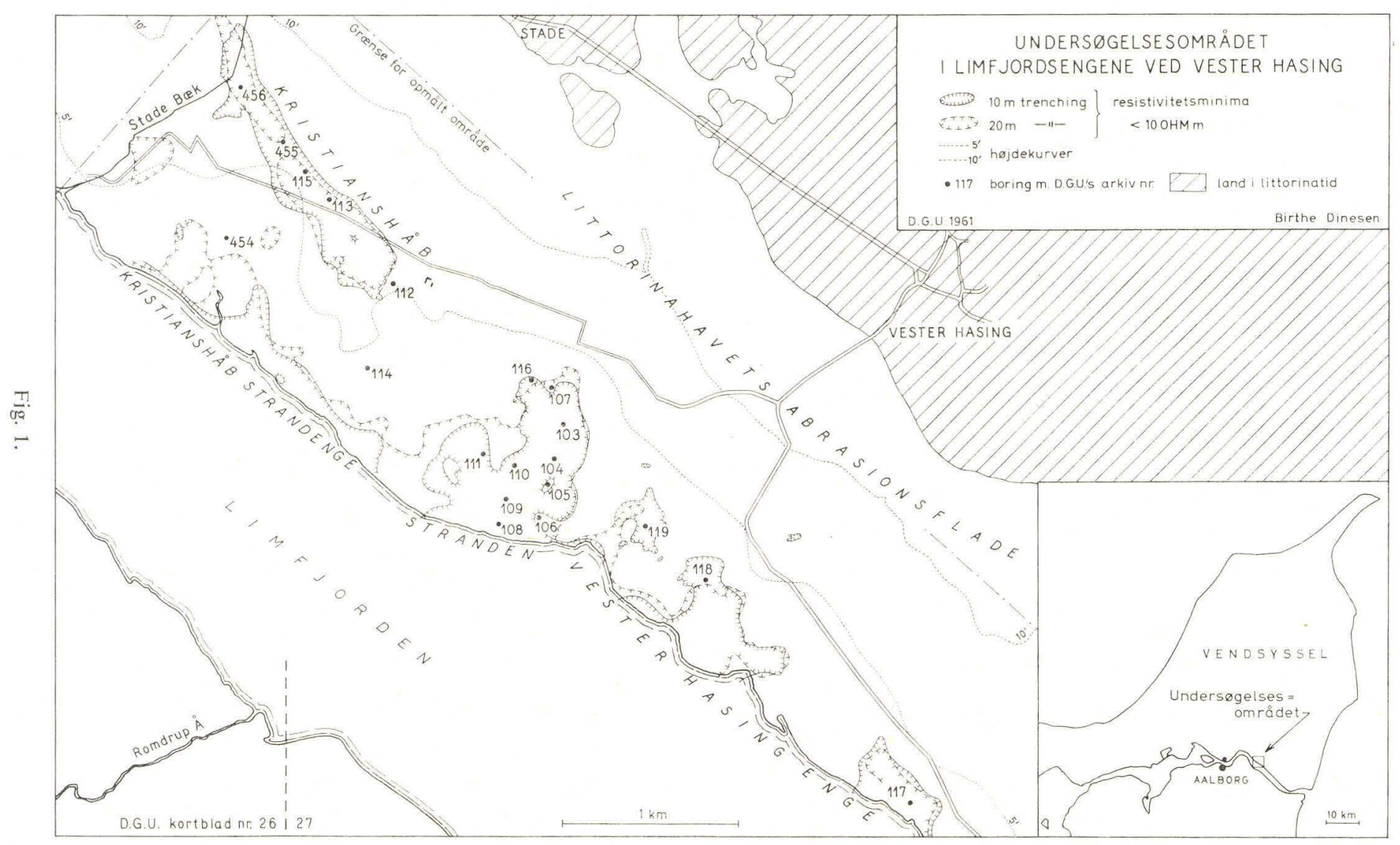




\section{INDLEDNING}

\section{Den geoelektriske kortlægnings metodik}

I 1955 har Th. Sorgenfrei behandlet teorien for den geoelektriske prospektering og samtidig gjort rede for resultaterne af de første danske undersøgelser af denne art.

Fremgangsmåden ved den anvendte metode er i korthed følgende:

Ved hjælp af 2 elektroder frembringes et vekselstrømsfelt i de øvre jordlag. Potentialforholdene måles med 2 elektroder anbragt mellem strømelektroderne, således at de 4 elektroder er anbragt på linie med samme indbyrdes afstand. Den gennemsnitlige specifike elektriske modstand for jordlagene ned til en dybde svarende til elektrodeafstanden beregnes ved sammenligning med en variabel erstatningsmodstand, der kan indskydes i potentialkredsløbet.

Kortlægningen baseres som regel på en kombination af linieprofil- og punktprofilopmålinger. Ved linieprofilopmåling, også kaldet kartering eller trenching, arbejdes med konstant elektrodeafstand, idet hele elektrodesystemet flyttes langs linier, der fastlægges på forhånd. På grundlag af disse målinger udarbejdes resistivitetskort, som giver overblik over horisontale variationer i jordlagenes modstand.

Ved punktprofilopmåling udføres målinger med voksende elektrodeafstand ud fra et fast punkt i terrænet. På grundlag af disse målinger udarbejdes punktprofildiagrammer, der muliggør en bedømmelse af vertikale variationer i jordlagenes modstand.

\section{Undersøgelsen i Limfjordsengene}

Formålet med den geoelektriske undersøgelse i Limfjordsengene var at lokalisere lerforekomster.

Opmålingsarbejdet blev forestået af N. V. JESSEN og B. BAGGE. Der udførtes linieprofilopmåling med en elektrodeafstand på henholdsvis 10 og $20 \mathrm{~m}$ i et område på $10 \mathrm{~km}^{2}$ nord for Limfjorden, øst for Aalborg som vist på kortet fig. 1, p. 8. På grundlag heraf udarbejdedes resistivitetskort, hvis kurvebillede var bestemmende for placeringen af punktprofilopmålingerne.

Tolkningen af måleresultaterne måtte imidlertid på forhånd anses for at være behæftet med en vis usikkerhedsfaktor, da der ud fra forhåndskendskabet til området kunne forventes betydelige variationer i istidslagene og deres hydrologiske forhold. Endvidere måtte det anses for sandsynligt, at der i det lave kystområde optrådte saltvand, som måtte virke forstyrrende med hensyn til afgrænsningen af lerlag. 
Undersøgelsesprogrammet blev derfor udvidet med 20 boringer, der fortrinsvis blev placeret i områder med elektriske modstandsminima, hvor man kunne forvente tilstedeværelse af lerforekomster af relativ stor mægtighed. Boringerne har D.G.U. arkivnumrene 26.454-456 og 27.103-119; deres placering er vist på fig. 1 .

Borearbejdet blev udført af G. Jul. Christiansen, Skalborg. Boringerne udførtes som tørboringer; i ler boredes med snegl, i sand, grus og skrivekridt med ventilspand. Bor. 27.114 udførtes som 4"-boring, bor. 26.454 og 27.117 som 4"-boring fra 0-20 m og som $3^{\prime \prime}$-boring fra $20-40 \mathrm{~m}$, de øvrige boringer er udført som 3"-boringer.

Ved udtagning af lerprøver blev de nederste $20-25 \mathrm{~cm}$ af sneglens indhold skrabet rent, hvorefter der blev afskåret en prøve på ca. $1 \mathrm{~kg}$. I sand, grus og skrivekridt blev ventilspandens indhold tømt ud i en beholder, hvorpå der efter omrøring blev udtaget en prøve. Denne repræsenterer med enkelte undtagelser en middelprøve af de gennemborede lag fra et interval på $0,5 \mathrm{~m}$.

Der blev foretaget pumpning fra alle sandlag, efterhånden som boringen skred frem. I sand og grus benyttedes et 1,5 eller $2 \mathrm{~m}$ langt 2 "-filter nr. 14; i skrivekridt pumpedes uden filter med forerøret stående i kridtets overflade. Som regel var sedimenterne så finkornede, at bestemmelse af lagenes ydeevne ikke kunne foretages. Pumpningen udførtes med håndpumpe, og vandprøver blev udtaget, efter at borehullet var pumpet rent. Vandprøverne var enten på ca. 51 eller ca. $\frac{1}{2} 1$ (se tabel II, pp. 42-43).

Materialet fra boringerne, omfattende 786 boreprøver og 52 vandprøver, blev underkastet laboratorieundersøgelser. I det følgende fremlægges resultatet heraf, og de indvundne erfaringer sammenholdes med de geoelektriske måleresultater. 


\section{LABORATORIEUNDERSØGELSER}

\section{Undersøgelse af boreprøver}

Undersøgelsen af boreprøverne omfatter bestemmelse af prøvernes kalkindhold og saltholdighed samt deres vandige opslæmningers specifike elektriske modstand. Bestemmelserne er udført efter nedknusning af ler-, dynd- og skrivekridtprøverne, frasortering af grus og sten fra sandprøverne og tørring af materialet ved $105^{\circ} \mathrm{C}$.

\section{Kalkindhold}

Kalkindholdet er beregnet ud fra bestemmelse af prøvernes syreforbrug ved kogning med saltsyre - en metode, der forudsætter, at den forbrugte syremængde udelukkende anvendes til spaltning af tilstedeværende carbonater.

$1 \mathrm{~g}$ sand, ler eller dynd eller $\frac{1}{2} \mathrm{~g}$ skrivekridt blev tilsat $25 \mathrm{ml} 0,5 \mathrm{n}$ saltsyre og ca. $175 \mathrm{ml}$ destilleret vand. Efter kogning i 20 minutter til uddrivning af den frigjorte kuldioxyd titreredes den resterende syre med $0,5 \mathrm{n}$ natriumhydroxyd med fenolftalein som indikator.

Der blev ikke konstateret reaktioner mellem de tilsatte reagenser og andre komponenter end carbonater, f. eks. sulfider eller jernforbindelser. For lerprøvernes vedkommende må antages ionbytningsreaktioner ved behandlingen med henholdsvis syre og base. Sådanne reaktioners indflydelse på prøvernes syreforbrug er dog ikke undersøgt nærmere.

Kalkindholdet er opgivet som $\% \mathrm{CaCO}_{3}$.

\section{Saltholdighed}

Prøvernes saltholdighed er bestemt ved titrering af de opslæmninger, der blev fremstillet til ledningsevnebestemmelse. Efter ledningsevnebestemmelsen (se p. 12) tilsattes lidt aluminiumsulfat for at fremkalde koagulation af opslæmmede kolloider. Efter henstand et døgn i lukket kolbe udtoges et passende rumfang til chloridtitrering. Da aluminiumsulfat reagerer surt, tilsattes lidt natriumbicarbonat for at sikre et for titreringen velegnet $\mathrm{pH}$ (7-10). Der titreredes med 0,0141 n sølvnitrat med kaliumchromat som indikator. Ved uskarpt omslag, f. eks. i uklare farvede opslæmninger, overtitreredes med et par dråber, hvorefter der blev korrigeret ved titrering af en standard natriumchloridopløsning til samme farve.

Ved titrering med sølvnitrat direkte på en opslæmning af tørrede lerholdige prøver bestemmes ifølge S. GRIPENBerG (1934) og B. KullenberG (1952) kun 95-99\% af prøvernes virkelige chloridindhold. Dette forhold er ikke taget i betragtning ved beregning af prøvernes saltholdighed.

Saltholdigheden er opgivet som $\% \mathrm{Cl}^{-}\left(\mathrm{mg} \mathrm{Cl}^{-} / \mathrm{g}\right.$ tørstof $)$. 


\section{Specifik elektrisk modstand}

Opslæmningernes specifike modstand er beregnet ud fra bestemmelse af ledningsevnen (specifik modstand i $\mathrm{OHMm}=10$ : specifik ledningsevne $\mathrm{i}$ $\mathrm{mMHO}$ ).

Under udarbejdelsen af en metode til ledningsevnebestemmelsen undersøgtes ledningsevnens afhængighed af opslæmningens temperatur og koncentration samt af udludningstiden. Det viste sig herved, at ledningsevnen steg ca. $3 \%$ pr. ${ }^{\circ} \mathrm{C}$. I_edningsevnen voksede ligeledes med opslæmningens koncentration, men afhængigheden mellem de to størrelser varierede med jordartstypen. Udludning i et døgn måtte anses for tilstrækkelig, da længere behandlingstid ikke medførte større ledningsevne. En direkte sammenligning af opslæmningernes ledningsevne kan således foretages, når målingerne er udført ved samme temperatur i opslæmninger af samme koncentration ca. 1 døgn efter opslæmningernes fremstilling.

Ved bestemmelserne anvendtes følgende fremgangsmåde: I en tør kolbe blandedes $50 \mathrm{~g}$ prøve med $250 \mathrm{ml}$ destilleret vand, afmålt i målekolbe. Kolben blev forsynet med prop og rystet jævnligt i ca. 5 timer. Efter henstand til næste dag dekanteredes over i en anden tør kolbe, hvorefter der af denne opslæmning udtoges en delprøve til ledningsevnebestemmelse ved $21^{\circ} \mathrm{C}$. Bestemmelsen blev foretaget med en ledningsevnemåler type CDM 2 med målecelle type CDC 104 fra fa. Radiometer, København.

\section{Bestemmelsernes usikkerhed}

En del af prøverne blev underkastet kontrolbestemmelser. Antal af kontrollerede prøver fremgår af tabel $\mathrm{I}$. For et flertal af de kontrollerede prøver viste dobbeltbestemmelserne en spredning mindre end de i tabel I angivne værdier. Hvis dobbeltbestemmelsernes spredning var større, foretoges flere bestemmelser

Tabel I. Kontrolbestemmelser. Antal kontrollerede prøver og resultaternes MAXIMALE SPREDNING.

\begin{tabular}{|c|c|c|c|c|c|}
\hline & \multirow{2}{*}{ Jordartstype } & \multicolumn{2}{|c|}{ Kontrollerede prøver } & \multicolumn{2}{|c|}{ Maximal spredning } \\
\hline & & Antal & $\begin{array}{c}\% \text { af } \\
\text { total antal }\end{array}$ & $\%$ abs. & $\%$ rel. \\
\hline Kalkindhold & $\begin{array}{l}\text { sand } \ldots \ldots \ldots \ldots \\
\text { ler og dynd } \ldots \ldots \ldots \ldots \\
\text { skrivekridt } \ldots \ldots \ldots \ldots\end{array}$ & $\begin{array}{l}83 \\
28 \\
26\end{array}$ & $\begin{array}{l}14 \\
20 \\
35\end{array}$ & $\begin{array}{l}0,4 \\
0,4 \\
0,8\end{array}$ & \\
\hline $\begin{array}{l}\text { Saltholdighed } \\
\text { og lednings- } \\
\text { evne }\end{array}$ & $\begin{array}{l}\text { sand } \ldots \ldots \ldots \ldots \\
\text { ler og dynd } \ldots \ldots \ldots \ldots \\
\text { skrivekridt } \ldots \ldots \ldots \ldots\end{array}$ & $\begin{array}{r}145 \\
51 \\
15\end{array}$ & $\begin{array}{l}25 \\
37 \\
20\end{array}$ & & $\begin{array}{l}6 \\
6 \\
6\end{array}$ \\
\hline
\end{tabular}



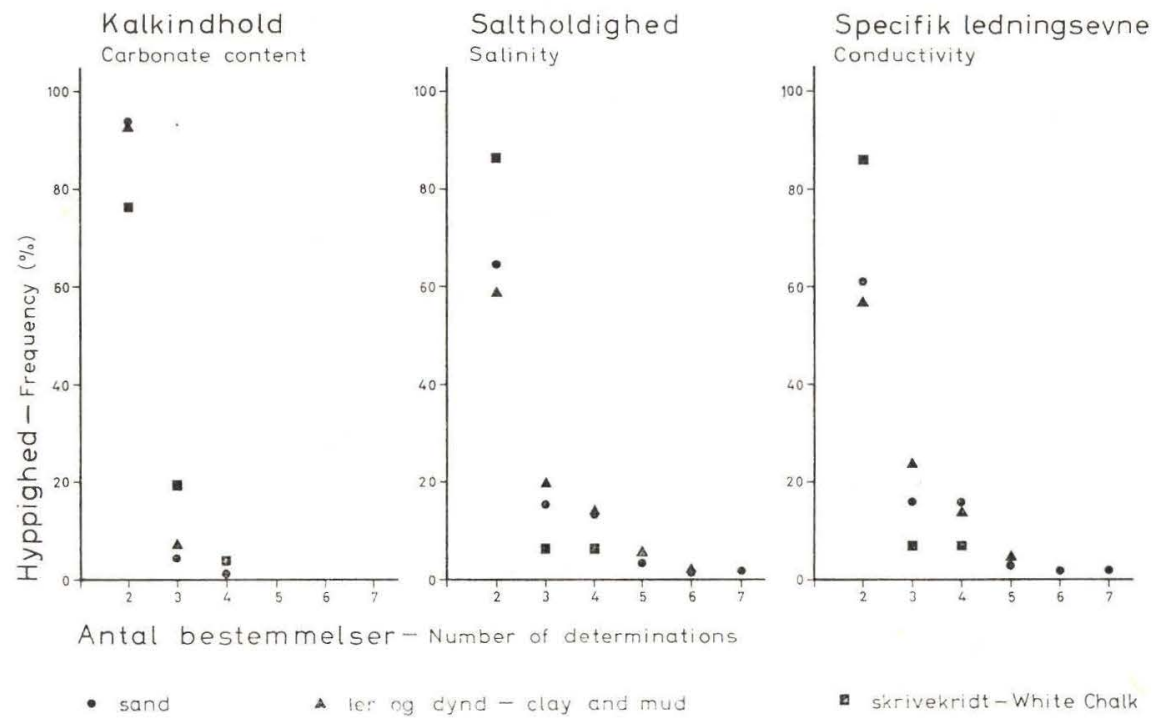

Fig. 2. Kontrolbestemmelser. Antal bestemmelser foretaget pr. kontrolleret prøve for at opnå 2 værdier med en spredning mindre end angivet i tabel I.

Check determinations. Number of determinations made per controlled sample to obtain 2 figures scattering less than indicated in table I.

pr. prøve, indtil der opnåedes 2 resultater med en spredning mindre end de angivne værdier.

Af fig. 2 fremgår, at usikkerheden på bestemmelse af henholdsvis saltholdighed og ledningsevne er større for sand, ler og dynd end for skrivekridt, medens usikkerheden på kalkbestemmelserne er størst for skrivekridtets vedkommende.

Den relativt store usikkerhed på bestemmelserne af saltholdighed for de lerholdige og humøse prøvers vedkommende må fortrinsvis tilskrives, at lerfraktionen og det organiske materiale kan medføre uklarhed og farvning af opsłæmningerne.

At ledningsevnebestemmelserne er mere usikre for sand, ler og dynd end for skrivekridt, må delvis være betinget af uensartede dispersionsforhold i opslæmninger, der indeholder ler eller organisk materiale. Endvidere må årsagen søges $i$ vanskeligheden ved at udtage en repræsentativ middelprøve til analyse. Da sand-, ler- og dyndprøverne er sammensat af komponenter med forskelligartede modstandsforhold (se pp. 30-35), vil usikkerhed ved prøveudtagningen øve indflydelse på ledningsevnen i opslæmninger af disse prøver; derimod vil den næppe være af betydning for skrivekridtopslæmningernes ledningsevne, da kridtprøverne består af komponenter med ensartede modstandsforhold (se p. 15 og p. 30).

Skrivekridtprøvernes vekslende forurening med sand medfører derimod en relativ stor usikkerhed på kalkbestemmelserne. 


\section{Vandanalyser}

Vandanalyserne omfatter bestemmelse af bicarbonat, sulfat, chlorid, calcium, magnesium, natrium og kalium samt for de fleste prøver $\mathrm{pH}$. For visse prøvers vedkommende er analyserne udvidet med bestemmelse af ammonium, nitrit, nitrat, fosfat, jern, mangan, kiselsyre og fri kulsyre. Natrium og kalium er bestemt flammefotometrisk, medens størrelsen natrium + kalium er beregnet som differens mellem negative og positive ækvivalenter og udtrykt som natrium. Calcium og magnesium er i de fleste tilfælde bestemt ved titrering med dinatriumversenat (komplexon III). De øvrige bestemmelser er foretaget efter DANSK STANDARD's forskrifter, dog med visse modifikationer for fosfat, jern og mangan.

Ved vurdering af vandanalyserne bør man være opmærksom på, at en del vandprøver kun var på ca. $\frac{1}{2} 1$, hvilket medfører nogen usikkerhed på analysematerialet. Endvidere foreligger en vis risiko for, at vandprøverne i nogle tilfælde kan være forurenet med vand fra borehullet, da der ikke kunne foretages langtidsprøvepumpning før udtagningen af vandprøverne. 


\section{SEDIMENTERNE}

\section{Prøvebeskrivelser}

Ved beskrivelserne er prøvernes kornstørrelse vurderet ved sammenligning med standardfraktioner. Der er anvendt følgende terminologi:

\begin{tabular}{|c|c|c|c|c|c|}
\hline & $\begin{array}{l}\text { Ler } \\
\text { mm }\end{array}$ & $\begin{array}{c}\text { Finsand } \\
\mathrm{mm}\end{array}$ & $\begin{array}{l}\text { Sand } \\
\mathrm{mm}\end{array}$ & $\begin{array}{c}\text { Grus } \\
\mathrm{mm}\end{array}$ & $\begin{array}{l}\text { Sten } \\
\mathrm{mm}\end{array}$ \\
\hline fint ............ & \multirow{3}{*}{$<0,002$} & $0,002-0,06$ & $0,2-0,6$ & $2,0-6,0$ & \multirow{3}{*}{$20,0<$} \\
\hline mellemkornet...... & & $0,06-0,1$ & $0,6-1,0$ & $6,0-10,0$ & \\
\hline groft............. & & $0,1-0,2$ & $1,0-2,0$ & $10,0-20,0$ & \\
\hline
\end{tabular}

Betegnelsen dynd er anvendt for humøse, mørktfarvede prøver, der har ringe vægtfylde, udviser betydeligt tørringssvind og efter tørring vanskeligt nedbrydes mekanisk i vand. Den minerogene fraktion udgøres overvejende af ler.

Visse prøver fra boringernes øverste afsnit er beskrevet som forvitrede. Det drejer sig om prøver med rustfarvede partier og pletvise udskillelser af et brunt, manganholdigt materiale, sandsynligvis brunsten $\left(\mathrm{MnO}_{2}\right)$.

En del skrivekridtprøver er opblandet med sand. Da sandet er feldspatholdigt og optræder som overtræk på brokker af sandfrit skrivekridt, må der være tale om nedfald fra de overliggende sandlag. Forureningen er sandsynligvis sket under borearbejdet. Sandets tilstedeværelse kan næppe sættes i forbindelse med karstfænomener, da det først optræder 5-10 m under skrivekridtets overflade.

Dybdeangivelserne betegner dybde under terræn. Terrænkoten for boringerne $26.454,27.103-111,27.114$ og 27.116-119 er mindre end $+5^{\prime}(+1,57 \mathrm{~m})$, for de øvrige boringer er den mellem $+5^{\prime}(+1,57 \mathrm{~m})$ og $+10^{\prime}(+3,14 \mathrm{~m})$ (se fig. 1, p. 8).

Vedrørende den stratigrafiske inddeling henvises til afsnittet om områdets geologi (pp. 36-39).

Arkiv nr. 26.454. Nørresund. Kristianshåb.

Prøvebeskrivelse.

0,5-1,0 m Ler, fedt, brunlig gråt, humøst, kalkholdigt.
Stratigrafisk inddeling.

Postglacialt ler 
1,5-2,0 - Dynd, let finsandet, mørkegråt, kalkholdigt; m. skalfragmenter (Littorina Postglacialt marint dynd littorea; Nassa reticulata).

2,0-9,0 - Finsand, mellemkornet-groft, gråt, kalkholdigt.

9,0-12,5 - Finsand, mellemkornet-gुroft, brunlig gråt, kalkholdigt.

12,5-16,0 - Finsand, groft, let sandet, brunlig gråt, kalkholdigt; m. enkelte kridtkorn;

Sen- eller fluvioglacialt sand enkelte bryozofragmenter.

16,0-22,0 - Finsand, fint-mellemkornet, let leret, gråt, kalkholdigt; m. enkelte kridtkorn.

22,0-33,0 - Skrivekridt, flintfrit.

33,0-40,0 - Skrivekridt, flintfrit, forurenet m. finsand.

Skrivekridt

Arkiv nr. 26.455. Nørresund. Kristianshåb.

Prøvebeskrivelse.

Stratigrafisk inddeling.

$0-0,5 \mathrm{~m} \quad$ Ler, fedt, grønlig gråt, kalkholdigt; forvitret; $m$. let finsandede, humøse partier; enkelte skalfragmenter (Littorina littorea). dannelser

1,0-1,5 - Dynd, let finsandet, mørkegråt, kalkholdigt; m. skalfragmenter (Littorina litiorea; Cardium sp.).

2,0-4,0 - Ler, fedt, grønlig gråt, kalkholdigt.

4,0- 4,5 - Ler, let finsandet, gråt m. brunlig tone, kalkholdigt.

5,0-11,5 - Ler, fedt, gråt, kalkholdigt; stedvis m. let finsandede partier.

11,5-14,0 - Finsand, groft, m. enkelte grovere sandog gruskorn, brunlig gråt, kalkholdigt; m. enkelte kridtkorn og små lerbrokker; enkelte forkullede planterester.

Senglacialt ler

14,0-20,0 - Finsand, mellemkornet-groft, m. enkelte grovere sand- og gruskorn, let leret, gråt, kalkholdigt; m. enkelte kridtkorn.

Sen- eller fluvioglacialt sand 
Arkiv nr. 26.456. Nørresund. Kristianshåb.

Prøvebeskrivelse.

0 - 0,5 m Ler, fedt, gråt, kalkholdigt; forvitret; m. slirer af finsand.

1,0- 1,5 - Ler, fedt, gråt, kalkholdigt; $m$. slirer af finsand.

2,0-2,5 - Ler, let finsandet, gråt, kalkholdigt.

2,5-6,0 - Finsand, groft, let sandet, brunlig gråt, kalkholdigt; m. bryozofragmenter.

6,0-11,0 - Finsand, groft, svagt sandet, brunlig gråt, kalkholdigt, $\mathrm{m}$. enkelte kridtkorn; m. bryozofragmenter; enkelte forkullede planterester.

11,0-11,5 - Ler, finsandet og let gruset, gråt, kalkholdigt; $m$. talrige små kridtbrokker.

11,5-18,0 - Skrivekridt, flintfrit.

18,0-20,0 - Skrivekridt, flintfrit; forurenet med finsand.

Arkiv nr. 27.103. Nørresund. Stranden.

\section{Prøvebeskrivelse.}

$0-0,5 \mathrm{~m}$ Ler, let finsandet, grønlig gråt, kalkholdigt; forvitret.

$1,0-1,5$ - Ler, fedt, grønlig gråt, kalkholdigt; m. slirer af finsand; enkelte skalfragmenter (Littorina littorea).

$2,0-2,5$ - Ler, svagt finsandet, grønlig gråt, kalkholdigt.

$3,0-7,5$ - Ler, fedt, gråt, kalkholdigt; stedvis m. enkelte slirer af finsand.

7,75-8,75 - Finsand, sandet og let gruset, mørkegråt, kalkholdigt; m. lerbrokker og talrige små kridtbrokker.

8,75-14,75 - Finsand, mellemkornet-groft, m. enkelte sand- og gruskorn, let leret, gråt; kalkholdigt; stedvis m. enkelte lerbrokker og små kridtbrokker; enkelte forkullede planterester.

14,75-15,25 - Finsand, mellemkornet-groft, stærkt leret, gråt, kalkholdigt; $m$. enkelte forkullede planterester.
Stratigrafisk inddeling.

Postglacialt ler?

Sen- eller fluvioglacialt sand

Moræneler

Skrivekridt

Stratigrafisk inddeling.

Postglacialt ler

Postglacialt marint ler

Senglacialt ler

Sen- eller fluvioglaciale dannelser 
15,25-16,25 - Ler, stærkt finsandet, lyst gråt, kalkholdigt.

16,25-19,75 - Finsand, fint-mellemkornet, let leret, gråt, kalkholdigt.

Arkiv nr. 27.104. Nørresund. Stranden.

Prøvebeskrivelse.

Stratigrafisk inddeling.

$0-0,5 \mathrm{~m} \quad$ Ler, let finsandet, grønlig gråt, kalkholdigt; forvitret; $m$. enkelte skalfragmenter.

Postglacialt ler

1,0-1,5 - Ler, let finsandet, mørkt grønlig gråt, humøst, kalkholdigt; $m$. partier af mørkegråt dynd; enkelte skalfragmenter (Littorina littorea).

2,0-2,25- Dynd, let finsandet, mørkegråt, kalkholdigt; m. skalfragmenter (Littorina littorea; Rissoa sp.).

2,25-9,5 - Ler, fedt, gråt, kalkholdigt; stedvis m. slirer af finsand.

9,5-10,0 - Finsand, sandet og gruset, m. enkelte sten, gråt, kalkholdigt; $\mathrm{m}$. lerbrokker og talrige små kridtbrokker.

10,0-11,5 - Finsand, let sandet, m. enkelte gruskorn, gråt, kalkholdigt; m. lerbrokker og små kridtbrokker.

11,5-16,0 - Finsand, mellemkornet, let leret, gråt, kalkholdigt; m. enkelte små lerbrokker, stedvis $\mathrm{m}$. enkelte kridtkorn.

Postglaciale marine dannelser

Senglacialt ler

Sen- eller fluvioglaciale dannelser

16,0-17,5 - Finsand, mellemkornet, let leret, grår, kalkholdigt; m. lerbrokker.

17,5-18,5 - Ler, fedt, lyst gråt, kalkholdigt; $\mathrm{m}$. partier af finsand.

18,5-20,0 - Finsand, fint-mellemkornet, let leret, gråt, kalkholdigt.

Arkiv nr. 27.105. Nørresund. Stranden.

Prøvebeskrivelse.

Stratigrafisk inddeling.

$0-0,5 \mathrm{~m} \quad$ Ler, let finsandet, grønlig gråt, kalkholdigt; forvitret.

Postglacialt ler 
1,0-1,5 - Dynd, let finsandet, mørkegråt, kalkholdigt; m. skalfragmenter (Littorina littorea; Littorina rudis).

1,6-2,0 - Finsand, groft, grăt, kalkholdigt; m.

Postglaciale marine stærkt lerede partier; m. skalfragmenter (Cardium sp.).

2,5-2,63 - Finsand, groft, m. enkelte sand- og gruskorn, gråt, kalkholdigt; m. ler- og kridtbrokker.

3,0-7,5 - Ler, fedt, gråt, kalkholdigt; stedvis m. enkelte slirer af finsand.

dannelser

Senglacialt sand

Senglacialt ler

7,5-8,0 - Sand, fint, finsandet, gråt, kalkholdigt; $\mathrm{m}$. små kridtbrokker; bryozofragmenter.

$8,0-8,5$ - Sand, finsandet, gråt, kalkholdigt; m. små kridtbrokker; bryozofragmenter.

8,5-9,0 - Sand, finsandet og gruset, gråt, kalkholdigt; $m$. lerbrokker og kridtbrokker.

9,0-10,0 - Finsand, groft, m. grus og sten, leret, gråt, kalkholdigt; m. kridtbrokker.

Sen-eller fluvioglaciale dannelser

10,0-11,0 - Ler, let finsandet, lyst gråt, kalkholdigt; m. partier af lyst gråt finsand.

11,0-14,5 - Finsand, fint-mellemkornet, let leret, gråt, kalkholdigt.

14,5-20,0 - Finsand, mellemkornet-groft, gråt, kalkholdigt.

Arkiv nr. 27.106. Nørresund. Stranden.

Prøvebeskrivelse.

$0-0,5 \mathrm{~m} \quad$ Ler, let finsandet, grønlig gråt, kalkholdigt; forvitret; $\mathrm{m}$. enkelte skalfragmenter.

1,0-1,5 - Dynd, let finsandet, mørkegråt, kalkholdigt; m. skalfragmenter (Littorina sp.).

1,5-2,0 - Sand, fint, finsandet, m. enkelte grovere korn, mørkegråt, kalkfrit.

2,0-2,5 - Sand, fint, finsandet, m. enkelte grovere korn, mørkegråt, kalkfrit; m. et enkelt skalfragment.
Stratigrafisk inddeling.

Postglacialt ler

Postglaciale marine dannelser 
$2,5-6,0$ - Sand, fint, finsandet, m. enkelte grovere korn, brunlig gråt, kalkfrit; stedvis m. enkelte små lerbrokker.

$6,0-8,0-\quad$ Sand, fint, finsandet, m. enkelte grovere korn, brunlig gråt, kalkholdigt, m. enkelte lerbrokker og kridtkorn; enkelte bryozofragmenter.

8,0-10,0 - Ler, fedt, gråt, kalkholdigt; stedvis m. enkelte slirer af finsand; fra $8,0-9,0 \mathrm{~m} \mathrm{~m}$. enkelte kridtbrokker.

10,0-11,0 - Sand, finsandet og let gruset, mørkegråt, kalkholdigt; $\mathrm{m}$. kridtbrokker og enkelte lerbrokker.

11,0-14,0 - Finsand, mellemkornet-groft, m. enkelte grovere korn, let leret, gråt, kalkholdigt; m. enkelte kridtkorn.

14,0-20,0 - Finsand, fint-mellemkornet, m. enkelte grovere korn, svagt leret, gråt, kalkholdigt.
Senglacialt sand

Senglacialt ler

Sen- eller fluvioglacialt sand

Arkiv nr. 27.107. Nørresund. Stranden.

Prøvebeskrivelse.

$0-0,5 \mathrm{~m} \quad$ Ler, let finsandet, grønlig gråt, let humøst, kalkholdigt; forvitret; $m$. enkelte planterester og skalfragmenter (Planorbis sp.).

1,0-5,0 - Ler, fedt, gråt, fra 2,0-2,5 m m. brunlig tone, kalkholdigt; stedvis $\mathrm{m}$. finsandede partier; m. enkelte små kridtbrokker.

5,0- 5,5 - Finsand, groft, let leret, brunlig gråt, kalkholdigt; m. enkelte gruskorn, lerbrokker og kridtkorn.

5,5-10,5 - Finsand, mellemkornet-groft, gråt, kalkholdigt; $\mathrm{m}$. enkelte lerbrokker, stedvis $\mathrm{m}$. enkelte kridtkorn.

10,5-13,5 - Finsand, mellemkornet-groft, let leret, gråt, kalkholdigt; m. enkelte lerbrokker.

13,5-17,5 - Finsand, mellemkornet-groft, let leret, gråt, kalkholdigt; m. enkelte lerbrokker og kridtkorn.

17,5-21,5 - Skrivekridt, flintfrit.
Stratigrafisk inddeling.

Postglacialt limnisk ler

Senglacialt ler

Sen- eller fluvioglacialt sand

Skrivekridt 
Arkiv nr. 27.108. Nørresund. Stranden.

Prøvebeskrivelse.

$0-0,5 \mathrm{~m}$ Sand, fint, finsandet, mørkegråt, humøst, kalkfrit; m. forkullede planterester; enkelte skalfragmenter (Cardium sp.).

0,5-1,0 - Sand, fint, finsandet, brunlig gråt, humøst, kalkfrit; m. partier af mørkegråt dynd; enkelte skalfragmenter (Cardium sp.).

1,0-5,0 - Finsand, fint-mellemkornet, let leret, gråt, kalkholdigt.

5,0-10,0 - Finsand, mellemkornet-groft, let leret, gråt, kalkholdigt.

10,0-12,5 - Finsand, groft, brunlig gråt, kalkholdigt; m. enkelte kridtkorn, enkelte bryozofragmenter.

12,5-13,5 - Finsand, brunlig gråt, kalkholdigt; m. enkelte forkullede planterester.

13,5-16,5 - Finsand, groft, let sandet, brunlig gråt, kalkholdigt; m. kridtkorn; bryozofragmenter.

16,5-20,0 - Sand, fint, finsandet, m. enkelte grovere korn, brunlig gråt, kalkholdigt; $m$. enkelte kridtkorn; enkelte bryozofragmenter.
Stratigrafisk inddeling.

Postglaciale marine

dannelser

Sen- eller fluvioglacialt

sand

Arkiv nr. 27.109. Nørresund. Stranden.

Prøvebeskrivelse.

$0-0,5 \mathrm{~m}$

Finsand, groft, lyst brunlig gråt, humøst, kalkfrit; $m$. enkelte forkullede planterester; enkelte skalfragmenter (Cardium sp.).

0,5-1,0 - Finsand, mellemkornet-groft, let leret, mørkegråt, humøst, kalkholdigt; m. forkullede planterester; enkelte skalfragmenter (Cardium sp.).

1,0- 5,0 - Sand, fint, finsandet, m. enkelte gruskorn, gråt, kalkfrit.

5,0- 5,5 - Sand, let gruset og stenet, mørkegråt, kalkholdigt; m. kridtbrokker og enkelte lerbrokker.

5,5-6,0 - Sand, fint-mellemkornet, let gruset og stenet, gråt, kalkholdigt; m. kridtbrokker.
Stratigrafisk inddeling.

Postglacialt marint sand

Sen- eller fluvioglacialt sand 
6,0-6,5 - Sand, fint-mellemkornet, let gruset, gråt, kalkholdigt; m. enkelte kridtkorn; enkelte bryozofragmenter.

6,5-8,0 - Sand, fint-mellemkornet, let finsandet, $\mathrm{m}$. enkelte gruskorn, gråt, kalkholdigt; m. enkelte kridtkorn; enkelte bryozofragmenter.

8,0- 9,5 - Finsand, mellemkornet-groft, svagt sandet, let leret, gråt, kalkholdigt; $\mathrm{m}$. brokker af finsandet, lyst gråt ler.

9,5-11,0 - Finsand, groft, let sandet, m. enkelte gruskorn, let leret, gråt, kalkholdigt; $\mathrm{m}$. enkelte brokker af finsandet, lyst gråt ler.

11,0-12,5 - Finsand, groft, m. enkelte sand- og gruskorn, svagt leret, gråt, kalkholdigt; m. enkelte kridtkorn.

12,5-16,0 - Finsand, mellemkornet-groft, m. enkelte sandkorn, gråt, kalkholdigt; enkelte kridtkorn.

16,0-17,5 - Finsand, mellemkornet-groft, m. enkelte grovere sand- og gruskorn, let leret, gråt, kalkholdigt; $\mathrm{m}$. enkelte kridtbrokker.

17,5-20,0 - Finsand, mellemkornet-groft, m. enkelte grovere sand- og gruskorn, leret, gråt, kalkholdigt; m. enkelte små kridtbrokker.

Arkiv nr. 27.110. Nørresund. Stranden.

Prøvebeskrivelse.

Stratigrafisk inddeling.

$0-0,5 \mathrm{~m} \quad$ Finsand, mellemkornet-groft, stærkt leret, grønlig gråt, kalkholdigt; forvitret; $\mathrm{m}$. humøse partier; forkullede planterester; enkelte stærkt nedbrudte skalfragmenter.

0,5-1,0 - Finsand, groft, mørkegråt, humøst, kalkfrit; m. partier af mørkegråt dynd og finsandet, humøst, grønlig gråt ler; m. talrige forkullede planterester; et enkelt skalfragment.

1,0-2,0 - Finsand, groft, m. grovere sandkorn og enkelte gruskorn, mørkegråt, kalkfrit; humøst; $m$. forkullede planterester.

2,0-8,0 - Finsand, mellemkornet-groft, m. enkelte grovere korn, leret, mørkegråt; kalkholdigt. 
8,0-10,5 - Finsand, mellemkornet-groft, m. enkelte grovere korn, let leret, gråt, kalkholdigt; fra $10,0-10,5 \mathrm{~m}$ m. enkelte kridtkorn.

10,5-20,0 - Sand, fint, finsandet, m. enkelte grovere sand- og gruskorn, brunlig gråt; kalkholdigt; $m$. enkelte kridtkorn; enkelte bryozofragmenter.

Arkiv nr. 27.111. Nørresund. Stranden.

Prøvebeskrivelse.

$0-0,5 \mathrm{~m}$ Dynd, let finsandet, mørkegråt, kalkholdigt; m. forkullede planterester; skalfragmenter (Littorina littorea).

0,5-6,0 - Sand, fint, finsandet, m. enkelte gruskorn, gråt, svagt kalkholdigt; $m$. enkelte kridtkorn.

6,0- 9,0 - Ler, fedt, gråt, kalkholdigt; m. let finsandede partier; stedvis enkelte små kridtbrokker.

9,0-13,0 - Finsand, mellemkornet-groft, m. enkelte grovere korn, leret, gråt, kalkholdigt; m. kridtkorn.

13,0-15,0 - Finsand, mellemkornet-groft, m. enkelte grovere korn, svagt leret, gråt; kalkholdigt.

15,0-16,5 - Finsand, sandet og gruset, let leret, grăt, kalkholdigt; m. talrige små kridtbrokker.

16,5-17,0 - Finsand, let sandet og gruset, let leret, gråt, kalkholdigt; m. små kridtbrokker.

17,0-20,0 - Sand, fint, finsandet, brunlig gråt, kalkholdigt; m. kridtkorn; m. bryozofragmenter.

Arkiv nr. 27.112. Nørresund. Kristianshåb.

Prøvebeskrivelse.

0 - 2,0 m Finsand, let leret, grålig brunt, humøst, kalkfrit; m. brokker af brunligt dynd og sortbrun tørv.

2,5-3,0 - Finsand, groft, let sandet, gråt, kalkholdigt; m. enkelte lerbrokker.
Stratigrafisk inddeling.

Postglacialt marint dynd

Senglacialt sand

Senglacialt ler

Sen- eller fluvioglacialt sand

Stratigrafisk inddeling.

Postglaciale dannelser

Senglacialt sand 
3,0- 3,5 - Ler, fedt, grønlig gråt, kalkholdigt.

3,5-9,0 - Ler, fedt, gråt, kalkholdigt; stedvis m. slirer af finsand.

9,0-11,0 - Finsand, mellemkornet-groft, let leret, gråt, kalkholdigt.

11,0-13,0 - Sand, fint-mellemkornet, finsandet, $\mathrm{m}$. enkelte gruskorn, let leret, gråt, kalkholdigt; m. små kridtbrokker; m. bryozofragmenter.

13,0-15,5 - Sand, fint-mellemkornet, finsandet, let Sen- eller fluvioglacialt gruset, let leret, gråt, kalkholdigt; m. små kridtbrokker; m. bryozofragmenter.

15,5-20,0 - Sand, finsandet, gruset, let stenet, gråt, kalkholdigt; m. kridtbrokker; m. bryozofragmenter.

Arkiv nr. 27.113. Nørresund. Kristianshåb.

Prøvebeskrivelse.

$0-0,5 \mathrm{~m}$ Finsand, groft, let sandet, brunlig gråt, kalkfrit; m. forkullede planterester.

1,0-13,0 - Ler, fedt, gråt, kalkholdigt; stedvis m. slirer af finsand.

13,0-16,5 - Finsand, mellemkornet-groft, m. grovere sand- og gruskorn, svagt leret, gråt, kalkholdigt; stedvis m. enkelte små lerbrokker; enkelte forkullede planterester.

16,5-20,0 - Finsand, mellemkornet-groft, let sandet og gruset, gråt, kalkholdigt; m. enkelte små kridtbrokker. sand

\section{Senglacialt ler}

Stratigrafisk inddeling.

Postglacialt sand?

Senglacialt ler

Sen- eller fluvioglacialt sand

\section{Prøvebeskrivelse.}

$0-0,5 \mathrm{~m} \quad$ Sand, fint, finsandet, $\mathrm{m}$. enkelte gruskorn og sten, grålig brunt, kalkfrit.

0,5-1,0 - Sand, fint, finsandet, m. enkelte gruskorn og sten, grålig brunt, kalkfrit; m. enkelte lerbrokker.

1,0-1,5 - Finsand, groft, grảlig brunt, kalkfrit; m. enkelte forkullede planterester.
Stratigrafisk inddeling.

Postglacialt sand? 
1,5- 3,5 - Finsand, groft, let sandet, brunlig gråt, kalkholdigt.

3,5-5,0 - Sand, fint, finsandet, brunlig gråt, kalkholdigt.

5,0- 6,5 - Sand, fint, finsandet, brunlig gråt, kalkholdigt; $m$. enkelte kridtkorn; enkelte bryozofragmenter.

6,5-10,5 - Finsand, groft, m. enkelte grovere korn, brunlig gråt, kalkholdigt; m. enkelte kridtSen- eller fluvioglaciale korn; enkelte bryozofragmenter.

10,5-11,5 - Finsand, groft, sandet og let gruset, brunlig gråt, kalkholdigt; m. små kridtbrokker; m. bryozofragmenter.

11,5-20,0 - Sand og grus, finsandet og stenet, gråt, kalkholdigt; m. kridtbrokker; enkelte bryozofragmenter.

Arkiv nr. 27.115. Nørresund. Kristianshåb.

Prøvebeskrivelse.

$0-0,5 \mathrm{~m}$ Ler, finsandet, grønlig gråt, let humøst, kalkholdigt; forvitret; $m$. enkelte skalfragmenter.

1,0-2,5 - Dynd, let finsandet, mørkegråt, kalkholdigt; m. skalfragmenter (Littorina littorea, Littorina rudis).

2,5-3,0 - Tørv, sortbrun.

3,0-11,5 - Ler, fedt, gråt, kalkholdigt; stedvis m. enkelte slirer af finsand.

11,5-12,0 - Sand, gruset og stenet, leret, gråt, kalkholdigt.

12,0-13,0 - Sand, finsandet, gruset, svagt leret, gråt, kalkholdigt.

13,0-14,5 - Ler, stærkt finsandet, let gruset, gråt, kalkholdigt; m. kridtbrokker.

14,5-19,0 - Grus og sten, sandet, gråt, kalkholdigt.

19,0-19,5 - Sand, gruset, let stenet, let leret, gråt, kalkholdigt.

19,5-20,0 - Ler, stærk.t finsandet, gruset, let stenet, gråt, kalkholdigt; m. kridtbrokker.
Stratigrafisk inddeling.

Postglacialt ler

Postglacialt marint dynd

Postglacial limnisk tørv

Senglacialt ler

Sen- eller fluvioglaciale dannelser

Moræneler

Fluvioglacialt grus

Morænedannelser 
Arkiv nr. 27.116. Nørresund. Stranden.

Prøvebeskrivelse.

$0-0,5 \mathrm{~m} \quad$ Ler, fedt, grønlig gråt, kalkholdigt; forvitret; m. humøse partier; enkelte skalfragmenter.

0,5-1,0 - Ler, fedt, grønlig gråt, kalkholdigt; forvitret; $m$. enkelte skalfragmenter.

1,5- 2,0 - Finsand, grålig brunt, humøst, kalkfrit; m sortbrun tørv; enkelte skalfragmenter (Cardium sp.).

2,0-7,5 - Ler, fedt, gråt, kalkholdigt; stedvis m. slirer af finsand.

7,5-12,5 - Finsand, mellemkornet-groft, stærkt leret, gråt, kalkholdigt; $m$. enkelte kridtkorn.

12,5-18,0 - Skrivekridt, flintfrit; stedvis m. enkelte gruskorn.

Stratigrafisk inddeling.

Postglaciale dannelser

Senglacialt ler

Sen- eller fluvioglacialt sand

Skrivekridt

18,0-20,0 - Skrivekridt, flintfrit; forurenet m. finsand.

Arkiv nr. 27.117. Nørresund. Vester Hasing enge.

Prøvebeskrivelse.

$0-0,5 \mathrm{~m}$

Ler, stærkt finsandet, humøst, brunlig gråt, kalkholdigt; forvitret; $m$. enkelte forkullede planterester.

0,5-1,0 - Dynd, finsandet, mørkegråt, kalkholdigt; m. skalfragmenter (Littorina sp., Cardium sp., Rissoa sp.).

1,0- 4,0 - Dynd, stærkt finsandet, mørkegråt, kalkholdigt; m. skalfragmenter (Cardium sp.).

4,0-8,5 - Dynd, finsandet, mørkegråt, kalkholdigt; m. tang og skalfragmenter (overvejende Cardium sp. og Rissoa sp., stedvis Littorina sp.).

8,5-9,0 - Dynd, let finsandet, mørkegråt, kalkholdigt; $m$. talrige planterester og skalfragmenter (Cardium sp. og Rissoa sp.).

9,0-24,0 - Finsand, mellemkornet-groft, let leret, gråt, kalkholdigt; m. enkelte forkullede planterester; enkelte skalfragmenter.
Stratigrafisk inddeling.

Postglacialt ler

Postglaciale marine dannelser 
24,0-24,5 - Dynd, stærkt finsandet, brunlig gråt, kalkholdigt; m. enkelte skalfragmenter (Valvata macrostoma).

24,5-25,5 - Dynd, finsandet, brunlig gråt, kalkholdigt; m. skalfragmenter.

25,5-28,0 - Finsand, mellemkornet-groft, m. enkelte grovere korn, let leret, gråt, kalkholdigt; m. små svovlkiskonkretioner.

28,0-32,5 - Finsand, mellemkornet, let leret, gulliggråt, kalkholdigt; m. gulbrune partier (sandsynligvis jarosit, da jern og sulfat er påvist); enkelte forkullede planterester.

Sen- eller fluvioglacialt sand

32,5-40,0 - Finsand, mellemkornet-groft, stedvis m. enkelte gruskorn, let leret, gråt, med gulliggrå partier; enkelte forkullede planterester.

Arkiv nr. 27.118. Norresund. Stranden.

Prøvebeskrivelse.

$0-1,0 \mathrm{~m}$ Ler, finsandet, let humøst, grønlig gråt, kalkholdigt; forvitret.

1,5-2,0 - Dynd, let finsandet, mørkegråt, kalkholdigt; m. skalfragmenter (Littorina littorea).

2,5-3,0 - Finsand, leret, stærkt humøst, mørkegråt, kalkfrit; m. skalfragmenter (Cardium sp.).

3,0-7,0 - Finsand, mellemkornet-groft, m. enkelte grovere korn, leret, gråt, kalkholdigt; enkelte forkullede planterester.

7,0-11,0 - Ler, fedt, gråt, kalkholdigt; stedvis m enkelte slirer af finsand.

11,0-20,0 - Finsand, mellemkornet-groft, m. enkelte grovere korn, let leret, gråt; kalkholdigt.
Stratigrafisk inddeling.

Postglacialt ler

Postglaciale marine dannelser

Senglacialt sand

Senglacialt ler

Sen- eller fluvioglacialt sand

Arkiv nr. 27.119. Norresund. Stranden.

Prøvebeskrivelse.

$0-0,5 \mathrm{~m}$ Finsand, groft, let sandet, brunlig gråt, kalkfrit; m. lerbrokker.

1,0-6,0 - Ler, fedt, gråt, kalkholdigt; stedvis m. enkelte slirer af finsand.
Stratigrafisk inddeling.

Senglacialt sand

Senglacialt ler 


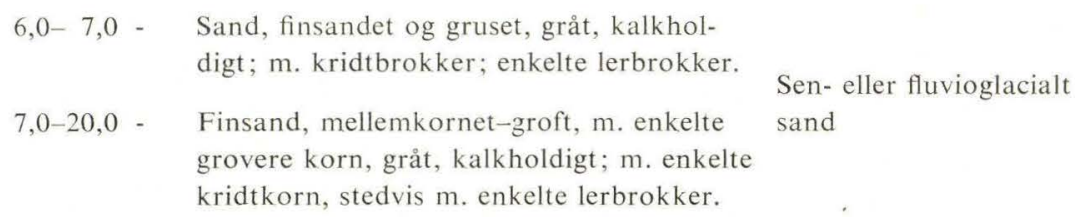

\section{Kalkindhold}

De analyserede prøvers kalkindhold er vist på tavle Ia-b.

Skrivekridtet indeholder gennemgående $80-95 \% \mathrm{CaCO}_{3}$. I de tilfælde, hvor et lavere kalkindhold er konstateret, står det i forbindelse med, at boreprøverne er forurenet med sand (se p. 15).

De kvartære sedimenters kalkindhold skyldes i vid udstrækning omlejrede øvrekretaciske kalkbjergarter; i de molluskførende sedimenter kan skalfragmenter endvidere give sedimentet et væsentligt tilskud af $\mathrm{CaCO}_{3}$. Den kemiske kalkudfældnings betydning for sedimenternes kalkindhold kan ikke bedømmes på grundlag af de foreliggende oplysninger om prøverne.

I de velsorterede sedimenter viser analyserne generelt et med finheden stigende kalkindhold, fra $3-5 \% \mathrm{CaCO}_{3}$ i fint sand til ca. $30 \% \mathrm{CaCO}_{3}$ i fedt ler.

Et relativt højt kalkindhold i forhold til kornstørrelsen kan optræde i moræneler og i gruset eller stenet sand på grund af tilstedeværelsen af kridtbrokker. I de dårligt sorterede sedimenter kan det konstaterede kalkindhold iøvrigt være højere end det reelle, da kalkbestemmelserne er foretaget efter frasortering af materiale over $2 \mathrm{~mm}$.

Humøse og overfladiske aflejringer viser gennemgående et relativt lavt kalkindhold $\mathrm{i}$ forhold til finheden. Dette kan stå i forbindelse med et kalkaggressivt miljø (se Wr. CHRISTENSEN, 1962), der må antages at være ret udbredt i de øvre jordlag som følge af nedbrydningsprocesser i de humøse overfladedannelser. For dyndets vedkommende må det lave kalkindhold være delvis betinget af den minerogene fraktions opblanding med organisk materiale.

\section{Saltholdighed}

Prøvernes saltholdighed fremgår af tavle Ia-b.

Lerprøverne må anses for at være forholdsvis intakte, da de udgør en afskåret del af boresneglens indhold. De tørrede lerprøvers saltholdighed kan derfor antages at have relation til sedimenternes naturlige saltholdighed.

Da prøverne ved analysen forelå i delvis lufttørret tilstand, kunne bestemmelse af det naturlige vandindhold ikke foretages. En bedømmelse af porevandets saltholdighed må derfor indskrænkes til skønsmæssige beregninger for aflejringer, hvis naturlige vandindhold erfaringsmæssigt varierer mellem ret snævre grænser. 
Sådanne beregninger er foretaget for det fede ler med ca. $30 \% \mathrm{CaCO}_{3}$. Dette ler antages at være identisk med det skalfrie senglaciale yoldialer, hvis naturlige vandindhold ifølge afdelingsgeolog, fru. E. L. MERTz varierer mellem 30 og $35 \%$ af tørstof (mundtlig oplysning).

På tavle $\mathrm{I} a-b$ er indtegnet saltholdigheden i denne lertypes porevand, beregnet for et vandindhold på henholdsvis $30 \mathrm{og} 35 \%$ af tørstof.

Af beregningerne fremgår, at variationen i de tørrede lerprøvers saltholdighed ikke udelukkende skyldes, at lerets naturlige vandindhold varierer mellem de nævnte grænser. Under forudsætning af, at disse grænser for det naturlige vandindhold ikke overskrides, må der optræde variationer i porevandets saltholdighed.

En sammenligning af den beregnede saltholdighed i lerets porevand med analyser af vandprøver fra de tilgrænsende sandlag viser, at porevandets saltholdighed sjældent er af samme størrelsesorden i de to sedimenttyper (se tavle Ia-b). I nogle boringer er lerets porevand mere saltholdigt end sandets, i andre gør det modsatte forhold sig gældende. Det må antages, at diffusionsprocesser samt bevægelse i grundvandet vil medføre en vis udveksling af opløste salte mellem ler- og sandlagene. Dette synes til eksempel at være tilfældet i bor. 27.106, hvor en med dybden voksende saltholdighed i leret fra 8,0-10,0 m kan skyldes påvirkning fra grundvandet $\mathrm{i}$ de tilgrænsende sandlag. Den kendsgerning, at lerlag af relativ stor mægtighed udviser den største saltholdighed (se bor. 26.455, 27.104, 27.115 og 27.113) taler endvidere for, at lerlagenes forskelligartede saltholdighed til en vis grad står i forbindelse med en uensartet udvaskning af det oprindelige saltindhold. Saltholdighedens relation til den geologiske udvikling i området er behandlet pp. 37-38.

Tilsvarende beregninger over porevandets saltholdighed er ikke foretaget for det øvrige ler på grund af manglende kendskab til lerets naturlige vandindhold. I særdeleshed bør bedømmelse af variationer i humøse prøvers saltholdighed foretages med varsomhed, idet selv et ganske ringe indhold af organisk materiale vil kunne øge et sediments naturlige vandindhold ganske betydeligt. Dette forhold er sandsynligvis en væsentlig årsag til den betydelige saltholdighed, der kan optræde i prøver af dynd, f. eks. i boringerne 27.104 og 27.117.

Saltholdigheden i de overfladiske lerlag af ret ringe mægtighed må i overvejende grad være bestemt af en vekslende nedsivning af ferskvand og af saltvand fra Limfjorden i forbindelse med oversvømmelser.

I modsætning til lerprøverne er prøverne af sand og skrivekridt ikke intakte. Porevandets mængde og sammensætning er ændret under borearbejde og prøveudtagning, og den saltholdighed, der er bestemt for disse prøver, er ikke identisk med sedimenternes naturlige saltholdighed.

Af fig. 3 fremgår, at der end ikke kan foretages en bedømmelse af ændringer i grundvandets saltholdighed ud fra sand- og skrivekridtprøvernes saltholdighed.

Punkternes spredning skyldes ikke variation i sedimenternes porøsitet. 


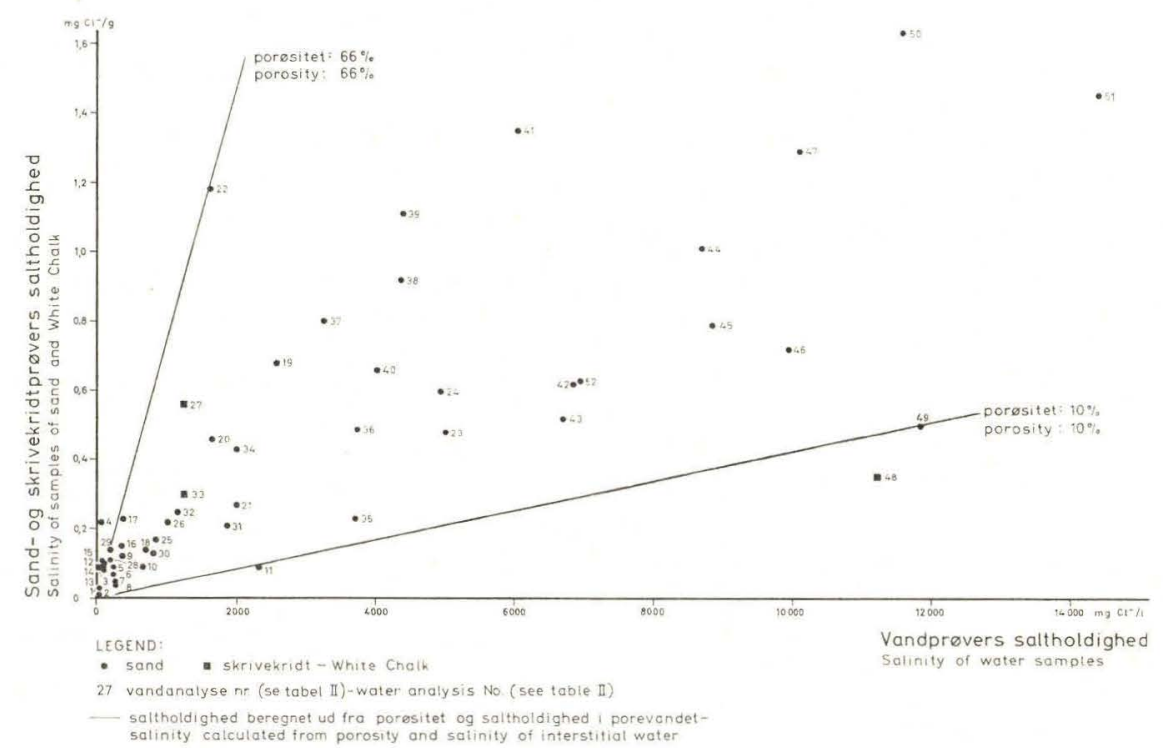

Fig. 3. Sand- og skrivekridtprøvers saltholdighed i forhold til grundvandets saltholdighed. Et punkt repræsenterer den gennemsnitlige saltholdighed i prøver fra et interval, hvorfra der er udtaget en vandprøve (se tabel II, pp. 42-43, og tavle Ia-b). De rette linier angiver den beregnede saltholdighed for intakte prøver (mineralkornenes vægtfylde sættes lig med $2,65)$.

Samples of sand and White Chalk. Salinity of samples related to salinity of ground water. A plot represents the average salinity of samples from an interval from where is taken a water sample (see table II, pp. 42-43, and plate Ia-b). Straight lines show calculated salinity of intact samples.

Eksempelvis kan porøsiteten for de intervaller, der repræsenteres af punkterne 22 og 49, beregnes til henholdsvis 66 og $10 \%$, medens den for de godt sammenrystede prøver er bestemt til henholdsvis 31 og $29 \%$. Bestemmelserne udførtes ved at veje et måleglas med $100 \mathrm{ml}$ sand, dels tørt og dels mættet med vand.

Sand- og skrivekridtprøvernes saltholdighed har således ikke relation til sedimenterne in situ. Størrelsen tjener udelukkende - sammenholdt med modstandsværdierne - til belysning af opslæmningernes modstandsforhold.

\section{Opslæmningernes specifike modstand}

Den specifike modstands afhængighed af saltholdighed og jordartstype kan vurderes ud fra de samhørende bestemmelser af boreprøvernes saltholdighed og opslæmningernes specifike modstand. Analyseresultaterne er afbildet i tavle Ia-b og fremstillet i form af gennemsnitsværdier i fig. 4.

Af fig. 4 fremgår, at sand- og kridtopslæmningernes specifike modstand i overvejende grad bestemmes af prøvernes saltholdighed, idet der er en tilnærmet omvendt proportionalitet mellem de to størrelser. For ler- og dynd- 


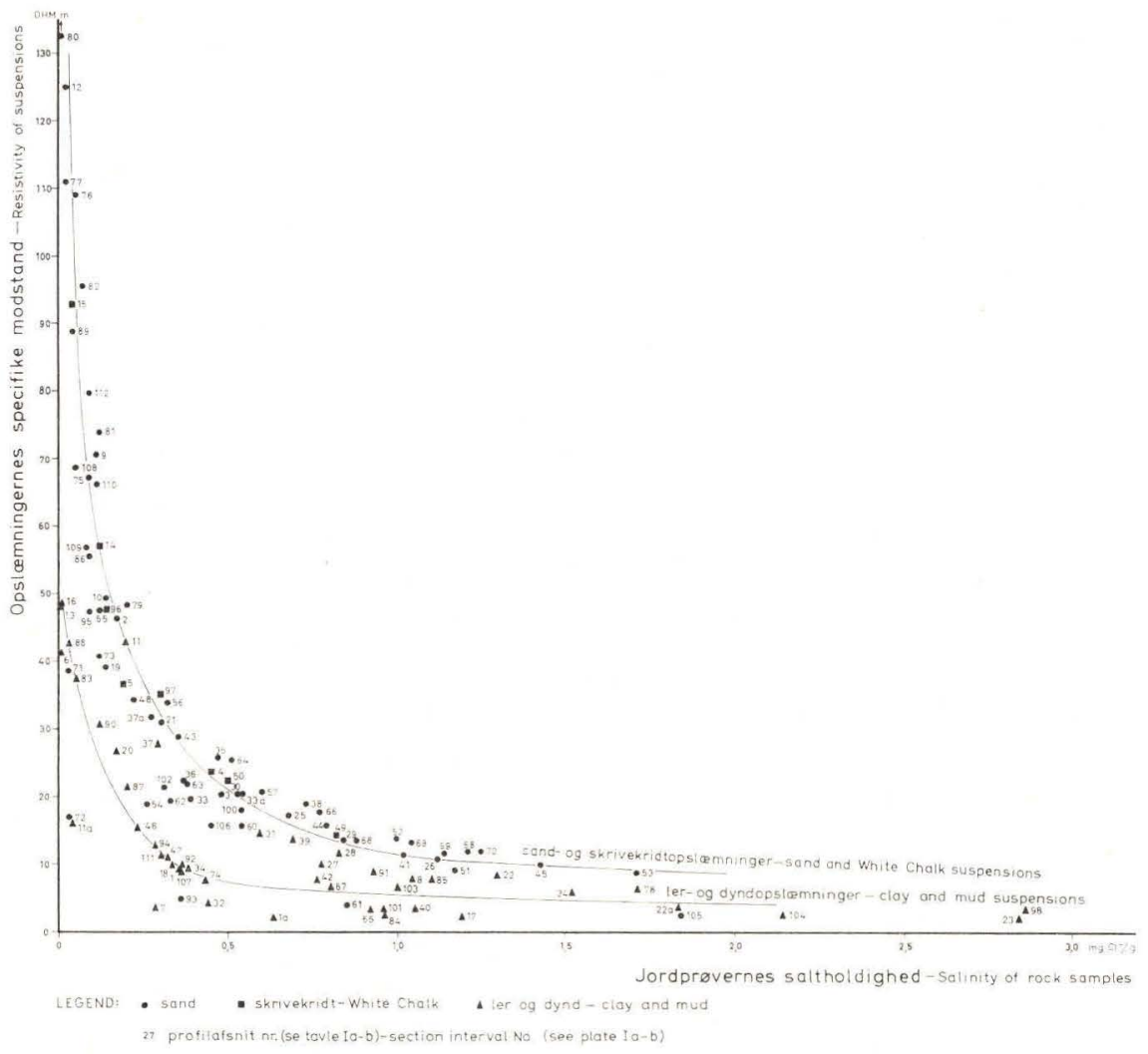

Fig. 4. Opslæmningernes specifike modstand i forhold til prøvernes saltholdighed. Punkterne repræsenterer gennemsnitsværdier for prøver fra profilafsnit som anført i tavle $\mathbf{I a}-\mathbf{b}$. Resistivity of suspensions related to salinity of samples. The plots represent mean values for samples from section intervals shown at plate $\mathrm{I} a-b$.

opslæmningernes vedkommende er modstandsværdierne lavere, og modstandens afhængighed af saltholdigheden er mindre udpræget. Disse forhold må være en følge af, at ler- og dyndopslæmningernes modstand ikke udelukkende bestemmes af prøvernes saltholdighed, men desuden påvirkes af indholdet af ler og organisk materiale med hertil knyttede uorganiske forbindelser. Det bemærkes, at punkterne i fig. 4 er underkastet en betydelig spredning, hvilket medfører, at de to kurver, der repræsenterer henholdsvis sand- og skrivekridtopslæmningernes og ler- og dyndopslæmningernes modstandsforhold, er behæftet med en vis usikkerhed. Årsagen til punkternes spredning må blandt andet søges i, at boreprøverne består af sand, ler og organisk materiale i vekslende blandingsforhold.

Størrelsesordenen af lerets og det organiske materiales ledende virkning kan skønsmæssigt anslås ud fra beregning af differensen mellem de reciproke ordi- 

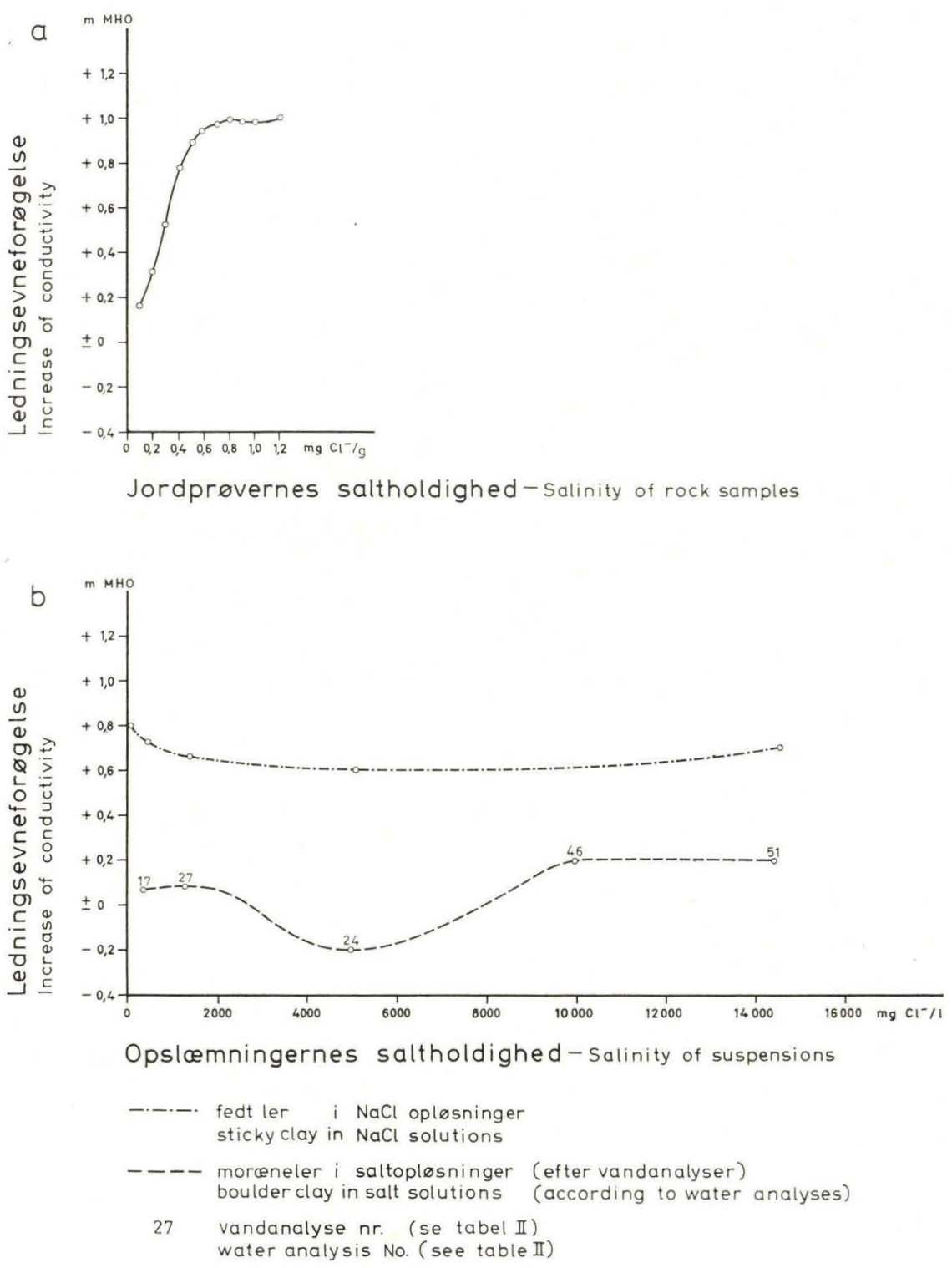

Fig. 5. Jordartens indflydelse på opslæmningernes ledningsevne. a) Differens mellem lerog dyndopslæmningernes og sand- og skrivekridtopslæmningernes ledningsevne (efter fig. 4). b) Differens mellem leropslæmningers og tilsvarende opløsningers ledningsevne.

Effect of rock type on conductivity of the suspensions. a) Difference between conductivity of clay- and mud suspensions and sand- and White Chalk suspensions (from fig. 4). b) Difference between conductivity of clay suspensions and corresponding solutions.

nater til kurverne i fig. 4. Resultatet af sådanne beregninger er afbildet i fig. $5 \mathrm{a}$. 
Af figurerne $4 \mathrm{og} 5 \mathrm{a}$ fremgår, at lerfraktionens ledningsevne ikke er konstant, men til eksempel er mindre for lerprøverne med under $0,1 \% \mathrm{Cl}^{-}$end for de mere saltholdige lerprøver med $0,3-0,5 \% \mathrm{Cl}^{-}$.

Lerfraktionens ledningsevne er betinget af lermineralernes dissociation. Denne varierer ifølge GRIM (1953, p. 135) blandt andet med leropslæmningernes koncentration, lermineralernes art og de adsorberede kationers art og relative koncentration. Eksempelvis er ifølge Marshall (1949, p. 115) dissociationsgraden for en $5 \%$ opslæmning af Na-illit lig med 0,10 , medens den for en tilsvarende opslæmning af Ca-illit er 0,04.

Forskellen i lerfraktionens ledningsevne for de saltfattige og de mere saltholdige lerprøver må således antages at være betinget af en forskel i de dissocierede ioners mængde og/eller art. Dette forhold er foreløbig kun belyst ved følgende forsøg:

1) Moræneler (bor. $26.456(11,0-11,5 \mathrm{~m}))$ med under $0,01 \%$ opslæmmet i forskellige saltopløsninger, fremstillet på grundlag af vandanalyser (se pp. 49-50). Differensen mellem ledningsevnen i opslæmningerne og i de anvendte saltopløsninger er afbildet i fig. $5 \mathrm{~b}$.

2) Fedt ler (bor. $27.105(3,0-3,5 \mathrm{~m}))$ med ca. 0,5\% $\% \mathrm{Cl}^{-}$blev opslæmmet i forskellige $\mathrm{NaCl}$-opløsninger. Differensen mellem ledningsevnen i opslæmningerne og i NaCl-opløsninger af samme chloridkoncentration er ligeledes afbildet i fig. 5 b.

Til orientering om arten af de to lertypers ombyttelige kationer blev prøver heraf opslæmmet et døgn i $0,1 \mathrm{~m} \mathrm{CaCl}_{2}(50 \mathrm{~g}$ prøve i $250 \mathrm{ml}$ opløsning). Ved denne behandling kunne der ikke konstateres Ca-optagelse i moræneleret, hvorimod det fede ler havde optaget ca. 5 mækv. Ca/100 g ler. Det må derfor antages, at moræneleret er Ca-ler, medens det fede ler sandsynligvis er Na-ler.

Af fig. $5 \mathrm{~b}$ fremgår, at lerfraktionens ledningsevne er større for opslæmningerne af det fede ler end for opslæmningerne af moræneleret. I hvilken udstrækning dette forhold er betinget af forskellen i henholdsvis de adsorberede kationers dissociationsgrad og lerfraktionens størrelse og sammensætning, kan ikke afgøres på grundlag af de foreliggende oplysninger. Visse træk ved kurveforløbet antyder dog forskellige faktorers indflydelse på lerets ledningsevne.

At lerfraktionens ledningsevne for opslæmningerne af det fede ler synes størst for de mindst salte opslæmningers vedkommende, kan stå i forbindelse med, at dissociationsgraden for Na-ler vokser med aftagende saltholdighed $\mathrm{i}$ væskefasen (se RoSENQVIST, 1955, pp. 45-53). For morænelerets vedkommende synes lerfraktionens ledningsevne mindre for opslæmningerne med under $2000 \mathrm{mg} \mathrm{Cl}-/ 1$ end for opslæmningerne med over $10000 \mathrm{mg} \mathrm{Cl}-/ \mathrm{l}$. Dette kan være en følge af, at Ca-leret ved behandling med de mest salte opløsninger omdannes til Na-ler; i så fald må kurvernes ordinatdifferens for saltholdigheder over $10000 \mathrm{mg} \mathrm{Cl}-/ 1$ overvejende være betinget af en forskel i lerfraktionens størrelse, eventuelt i dens sammensætning. Det må dog understreges, at den konstaterede ledningsevne for lerfraktionen i moræneleret er af samme stør- 
relsesorden som eller mindre end usikkerheden på målingerne. En nærmere bedømmelse af, hvilke faktorer der bestemmer lerfraktionens ledningsevne for de forskellige leropslæmninger kræver derfor mere detaljerede undersøgelser.

I denne forbindelse er det nærliggende at knytte nogle bemærkninger til en metode til bestemmelse af saltholdigheden i lers porevand ved ledningsevnemåling på et vandigt udtræk af leret. Ved anvendelse af denne metode bør man være opmærksom dels på lerfraktionens ledningsevne og dels på, at fortyndingen af lerets porevand kan medføre forskydning i ler- elektrolyt systemets ligevægtsforhold. RosEnQvist (1955, p. 65) angiver, at ledningsevnemåling på væskefasen efter fracentrifugering af lerpartiklerne giver et tilfredsstillende mål for porevandets saltholdighed i relativt salte lerprøver. Ledningsevnemåling på væskefasen i ligevægt med sedimenterede lerpartikler, eventuelt efter frafiltrering af ikke sedimenteret materiale, giver derimod for høje værdier for porevandets saltholdighed (SöDERBLOM, 1957). Årsagen hertil kan måske være en ufuldstændig adskillelse af lerpartiklerne fra væskefasen.

I det følgende foretages en kort gennemgang af opslæmningernes modstandsforhold for de forskellige sedimenters vedkommende. De skitserede træk illustreres i tavle Ia-b og fig. 4.

Sand- og skrivekridtopslæmningernes specifike modstand bestemmes som nævnt p. 30 væsentligst af prøvernes saltholdighed. I tavle Ia-b ses en tendens til konformitet mellem kurverne for saltholdighed og specifik modstand, idet modstanden generelt aftager med voksende saltholdighed.

Modstandsniveauet i forhold til saltholdigheden varierer med sandprøvernes indhold af ler eller organisk materiale. Lerindholdets betydning for sandopslæmningernes modstandsforhold illustreres f. eks. i bor. 27.110, hvor opslæmninger af leret finsand fra 2,0-8,0 $\mathrm{m}$ har mindre saltholdighed men samtidig lavere modstand end prøver af lerfrit sand fra 10,5-20,0 m. Det organiske materiales indflydelse på sandopslæmningernes modstand viser sig ved, at humøst sand kendetegnes ved ekstremt lave modstandsværdier, se f. eks. intervallerne bor. $27.112(0-2,0 \mathrm{~m})$ og $27.116(1,5-2,0 \mathrm{~m})$.

Leropslæmningernes modstand er generelt tydeligt lavere end sand- og skrivekridtopslæmningers af samme saltholdighed, men modstandsniveauet i forhold til saltholdigheden er varierende.

Opslæmninger af moræneler fra bor. $26.456(11,0-11,5 \mathrm{~m})$ samt bor. 27.115 (13,0-14,5 m) og (19,5-20,0 m) viser en forholdsvis høj specifik modstand. Det overfladiske forvitrede ler fra boringerne 26.455, 26.456, 27.103-106, $27.115 \mathrm{og}$ 27.116 kendetegnes ligeledes ved ret høje modstandsværdier, og tilsvarende gælder for det sandblandede ler fra bor. 27.103 (14,75-16,25 m), 27.104 (17,5$18,5 \mathrm{~m})$ og $27.105(10,0-11,0 \mathrm{~m})$. Opslæmninger af det fede ler med ca. $30 \%$ $\mathrm{CaCO}_{3}$ viser et lavere modstandsniveau end ovennævnte lertyper. Som nævnt p. 33 adskiller moræneleret fra bor. $26.456(11,0-11,5 \mathrm{~m})$ sig fra det fede ler fra bor. $27.105(3,0-3,5 \mathrm{~m})$ både med hensyn til lerfraktionens størrelse og de adsor- 
berede kationers art; men på grundlag af de foreliggende oplysninger kan der ikke foretages en generel vurdering af de forskellige faktorers indflydelse på leropslæmningernes modstandsniveau.

For dyndopslæmningernes vedkommende kan modstandsniveauet antage minimale værdier, se f. eks. bor. 26.454, 26.455, 27.104-106, 27.111, $27.115 \mathrm{og}$ 27.117-118. Årsagen hertil må søges i prøvernes indhold af organisk materiale (jfr. det humøse sands modstandsforhold). Tilsvarende lave modstandsværdier for leret fra bor. $26.456(1,0-2,5 \mathrm{~m})$ og $27.103(1,0-1,5 \mathrm{~m})$ kan tyde på, at der her er tale om humøst ler, uden at humusindholdet iøvrigt påvirker prøvernes makroskopiske karakter. 


\section{UNDERSØGELSESRESULTATERNES RELATION TIL OMRADETS GEOLOGI}

De geologiske forhold i området mellem Limfjorden og Vester Hasing bakkeø har tidligere været behandlet af A. JESSEN (1905 og 1936) i kortbladsbeskrivelsen til Aalborg-bladet og i oversigten over Vendsyssels geologi. JESSEN's beskrivelser kan kort sammenfattes i følgende oversigt.

Prækvartæret består af skrivekridt. Der er ikke konstateret interglaciale aflejringer i området, og de glaciale aflejringer må sandsynligvis henføres til sidste istid. På Vester Hasing bakkeø optræder israndsdannelser, der antages at være aflejret i forbindelse med en stilstandslinie eller en fremstødslinie for en indlandsis med nordøst - sydvestlig retning. Under isens afsmeltning lå landoverfladen i de nuværende Limfjordsenge under havniveau; det senglaciale havs strandlinier træffes således på de omkringliggende bakkeøer i kote $+20-+30 \mathrm{~m}$. I denne periode aflejredes sand (nedre og øvre saxicavasand) og skalfrit yoldialer. Ved den følgende landhævning må Limfjorden antages at være blevet tørlagt mindst ud til kote $\div 6-\div 7 \mathrm{~m}$. Forekomster af tørv fra fastlandstiden kendes fra en del lokaliteter i Limfjordsengene. Derefter transgrederede littorinahavet, hvis strandlinier nu findes ved kote ca. $+8 \mathrm{~m}$. I forbindelse med transgressionen aflejredes sand, ler og dynd. Senere hævedes havbunden til den nuværende sletteflade.

Resultaterne fra lerprospekteringen for Aalborg PORTLAND-CementFABRIK har givet os muligheder for en mere detaljeret udredning af de geologiske forhold. Materialet fra boringerne er ganske vist ikke underkastet mikrofossilundersøgelser, hvorfor en række stratigrafiske spørgsmål må henstå. I det følgende sammenholdes imidlertid resultaterne af sedimentundersøgelserne, som er fremlagt i de foregående afsnit, med de nævnte tidligere undersøgelser over den geologiske udvikling. Med hensyn til de lithologiske forhold henvises til profilerne på tavle $\mathrm{I} a-\mathrm{b}$. Sedimenternes regionale fordeling i området fremgår af fig. 6 , p. 40 .

Skrivekridtet er truffet i boringerne 26.454, 26.456, 27.107 og 27.116 i en dybde af 11-22 m. Der er utvivlsomt tale om faststående lag. I de øvrige boringer er kridtoverfladen ikke nået i en dybde af 20 m, i bor. 27.117 endnu ikke i $40 \mathrm{~m}$ dybde. Kridtoverfladen synes således at være ujævn, hvilket er i overensstemmelse med tidligere iagttagelser (JESSEN, 1936, p. 28). 
Glaciale aflejringer i form af morænedannelser eller fluvioglacialt sand og grus optræder i den nordvestlige del af området. I bor. 26.456 overlejres skrivekridtet af 0,5 m moræneler. I bor. 27.115 optræder moræne i tilknytning til fluvioglacialt sand og grus, der også træffes i de nedre afsnit af boringerne 27.112 og 27.114 .

I boringerne $27.103(7,75-8,75 \mathrm{~m}), 27.104(9,5-10,0 \mathrm{~m}), 27.105(8,5-10,0 \mathrm{~m})$, $27.106(10,0-11,0 \mathrm{~m}), 27.109(5,0-6,0 \mathrm{~m}), 27.111(15,0-17,0 \mathrm{~m})$ og 27.119 (6,0-7,0 m) optræder let lerholdigt, dårligt sorteret sand med et karakteristisk indhold af kridtbrokker. Betegnelsen »let udvasket morænesand « er dækkende for prøvernes udseende. Muligvis er der dog snarere tale om en dannelse, der svarer til det af JESSEN (1905, p. 108) omtalte nedre senglaciale strandsand, som antages overvejende at bestå af nedskyllet materiale fra bakkeøerne.

De dybere liggende kvartære lag udgøres iøvrigt i vid udstrækning af mere velsorteret materiale uden makrofossiler. Lagene kendetegnes ved en vis relation mellem kalkindhold og kornstørrelse. Sandlagenes kalkindhold varierer mellem 3 og $15 \% \mathrm{CaCO}_{3}$. Fra boringerne 27.103 (15,25-16,25 m), 27.104 (17,5-18,5 m) og $27.105(10,0-11,0 \mathrm{~m})$ består prøverne af lyst gråt ler opblandet med finsand; disse prøvers kalkindhold er på ca. $20 \% \mathrm{CaCO}_{3}$. Det drejer sig sandsynligvis om smeltevandsaflejringer, eventuelt om lag af senglacial oprindelse. JESSEN antyder således en relation mellem smeltevandssandets lerindhold og kalkindhold (1905, p. 46) og nævner, at kalkindholdet som regel er under $10 \% \mathrm{CaCO}_{3}$, men kan stige til $15-20 \% \mathrm{CaCO}_{3}$. For smeltevandslerets vedkommende anføres (1936, p. 47), at det gennemsnitlige kalkindhold er på 15$20 \% \mathrm{CaCO}_{3}$, men at der i visse tilfælde er fundet op til $36 \% \mathrm{CaCO}_{3}$.

I et flertal af boringerne udgør fedt, gråt ler uden makrofossiler et karakteristisk led i sedimentfølgen. Leret er enten underlejret af det før nævnte dårligt sorterede sand med kridtbrokker eller af de ovennævnte mere velsorterede sandlag. Det overlejres enten af postglaciale aflejringer eller af sand, der formentlig svarer til det af JESSEN (1905, p. 108) omtalte øvre senglaciale strandsand.

Leret indeholder ca. $30 \% \mathrm{CaCO}_{3}$. Med hensyn til kalkindhold adskiller det sig tydeligt fra det interglaciale skalførende aldre yoldialer, der kendes fra det nordlige og østlige Vendsyssel, idet dette oftest indeholder under $10 \%$ $\mathrm{CaCO}_{3}$ (Jessen, 1936, p. 45). På grundlag af kalkindholdet kan det derimod ikke afgøres, om der er tale om smeltevandsler eller senglacialt yoldialer. JESSEN (1936, p. 98) opgiver det gennemsnitlige kalkindhold i yoldialeret til 15-20\% $\mathrm{CaCO}_{3}$, men anfører, at det vokser med lerets finhed, idet det dog sjældent overskrider ca. $30 \% \mathrm{CaCO}_{3}$. Eksempelvis nævnes (1906, p. 96), at en prøve af yoldialer fra lergraven ved Kristianshåb Teglværk indeholdt $25,5 \% \mathrm{CaCO}_{3}$.

Lerets saltholdighed tyder på, at der ikke er tale om smeltevandsler. Der kan dog næppe foretages en bedømmelse af sedimentationsmiljøets saltholdighed ud fra lerprøvernes saltholdighed i lighed med de undersøgelser, B. Kullen- 
BERG (1952 og 1954) har foretaget på bundprøver fra Østersøen, idet forskellige undersøgelser har vist, at sen- og postglaciale lersedimenters oprindelige saltholdighed i en del tilfælde må være ændret efter sedimentationen. På grundlag af undersøgelser ved Præstø fjord antager V. MikKelsen (1956) til eksempel, at de postglaciale sedimenters oprindelige saltholdighed er ændret ved saltdiffusion. Endvidere har undersøgelser af norske marine sen- og postglaciale lersedimenters saltholdighed vist, at der efter sedimentationen er sket en vis udvaskning af disse lerlags oprindelige saltholdighed, samt at udvaskningsgraden vokser med sedimentets alder og i en del tilfælde med dets højde over det nuværende havniveau (se f. eks. R. W. Feyling-Hanssen, 1957, hvori findes henvisninger til tidligere norske arbejder vedrørende saltudvaskning $\mathrm{i}$ ler).

I betragtning af, at de her undersøgte lerlag må have været delvis hævet over havniveau i fastlandstiden, samt at området senere dækkedes af littorinahavet, er det overvejende sandsynligt, at lerets nuværende saltholdighed er ændret i forhold til aflejringsmiljøets saltholdighed. I boringerne 26.455, 27.104, 27.113 og 27.115 afspejler lerlagenes saltholdighed muligvis den geologiske udvikling efter lerets sedimentation. Det brede saltmaximum i lagenes midte kan således stå $\mathrm{i}$ forbindelse med, at der i fastlandstiden er sket en vis reduktion af det oprindelige saltindhold i lagenes øvre og nedre afsnit som følge af udvaskning og diffusion. Endvidere kan det skarpe maximum i lerets nedre og - i bor. 26.455, 27.113 og 27.115 - i dets øvre afsnit skyldes infiltration af saltvand, medens området var dækket af littorinahavet. I de øvrige boringer er saltholdigheden mindre og viser ikke en tilsvarende ensartet ændring med dybden. Dette kan næppe tages som udtryk for et andet aflejringsmiljø, men må snarere tilskrives en mere vidtgående ændring af lerets oprindelige saltholdighed. Bedst overensstemmelse mellem den nuværende og den oprindelige saltholdighed må forventes i leraflejringernes indre afsnit, der blandt de her udførte boringer antages at være repræsenteret af den midterste del af lerlaget $\mathrm{i}$ bor. 27.113. Porevandets saltholdighed $\mathrm{S}$ kan her beregnes til 11-13\% $\%$ (S \% $\%$ »havsalt $\left.«=1,808 \% \mathrm{Cl}^{-}+0,03\right)$. Til sammenligning kan nævnes, at varvigt ler fra Østersøen ved Bornholm ifølge KuLLENBERG (1952) indeholder porevand med en saltholdighed på 11-16\% som for leret i bor. 27.113. På grundlag af mikrofossilundersøgelser har FeyLing-HAnssen (1957) endvidere fundet, at visse marine sen- og postglaciale sedimenter i Oslofjord-området må antages at være afsat i vand med en saltholdighed på mindst $15 \%$, måske mindst $20 \%$, altså i vand med større saltholdighed end den, der er beregnet for porevandet i leret fra bor. 27.113.

En nærmere bedømmelse af det fede skalfrie lers aflejringsmiljø kan dog som nævnt næppe foretages på grundlag af det foreliggende materiale. Det kan således ikke afgøres, om leret er af senglacial eller af ældre kvartær oprindelse. Foreløbig må det i overensstemmelse med den hidtil gældende opfattelse antages, at det er senglacialt. 
Den nedre grænse for de postglaciale sedimenter er i de her omhandlede boringer som regel fastlagt på grundlag af prøvernes indhold af makrofossiler; i visse tilfælde er aflejringer henført til postglacialtiden på grund af prøvernes humøse karakter eller indhold af planterester. I bor. 26.456 anses leret fra 0-2,5 m for postglacialt på grund af det lave modstandsniveau (se p. 35).

Med hensyn til den postglaciale series mægtighed indtager bor. 27.117 en særstilling. Der er i denne boring konstateret postglaciale sedimenter til en dybde af 25,5 m, medens mægtigheden for de øvrige boringers vedkommende synes at være maximalt ca. $3 \mathrm{~m}$. Mikrofossilundersøgelser vil dog muligvis medføre en revision af grænsen mellem sen- og postglaciale aflejringer.

Postglaciale ferskvandsdannelser, der er overlejret af marine sedimenter og derfor sandsynligvis må henføres til fastlandstiden, optræder kun underordnet. I bor. 27.115 er konstateret tørv fra 2,5-3,0 m, medens der i boringerne 27.112 og 27.116 findes brokker af tørv i prøver af postglacialt sand. I bor. 27.117 optræder skalførende dynd, der på grundlag af et enkelt eksemplar af Valvata macrostoma antages at være en ferskvandsdannelse.

I bor. 27.107 optræder et overfladisk lag af ferskvandsler. Da der ikke optræder postglaciale marine dannelser i denne boring, kan det endnu ikke afgøres, om leret er aflejret før eller efter littorinatiden.

Det må antages, at de øvre jordlag har været underkastet forvitring og kalkudvaskning i fastlandstiden. Tilstedeværelse af kalkfrie eller kalkfattige sandlag til 5-6 m dybde i boringerne 27.106, 27.109 og $27.111 \mathrm{kan}$ være en følge af sådanne processer. I visse boringer f. eks. bor. 26.455, $27.112 \mathrm{og} 27.115 \mathrm{er}$ der et relativt lavt kalkindhold i det fede skalfrie lers øvre afsnit; om dette er betinget af kalkudvaskning eller en ændring i sedimentationsmiljøet, kan ikke afgøres. At der ikke generelt spores kalkudvaskning i leret, kan skyldes, at de øverste lerlag er borteroderet ved littorinahavets transgression.

Postglaciale marine aflejringer optræder i et flertal af boringerne. Serien udgøres i en del boringer af stærkt skalførende dynd overlejret af ler med mindre skalhyppighed; i andre boringer er sandlag dominerende. Området omkring bor. 27.117 må have indgået i det ret dybe sund, der langs Limfjorden strakte sig fra Kattegat mod Aalborg. Det øvrige område må have været en mere lavvandet bredning med stærkt varierende bund- og strømforhold. 


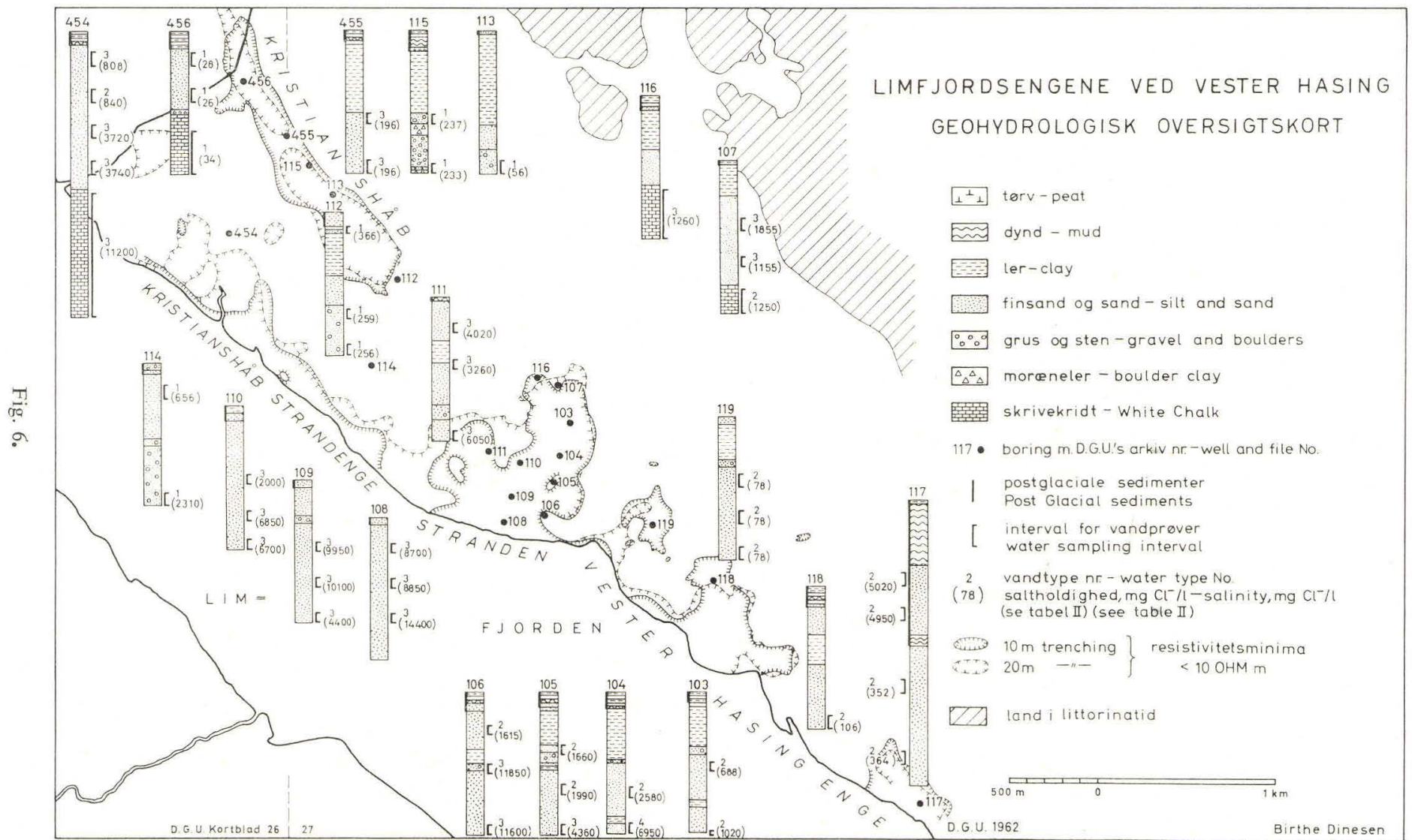




\section{GRUNDVANDET}

\section{Vandprøvernes kemiske sammensætning}

Resultatet af vandanalyserne er gengivet i tabel II, pp. 42-43, og afbildet grafisk i tavlerne Ia-b og II. Den grafiske fremstilling er baseret på komponenternes procentiske ækvivalentkoncentrationer, hvilket medfører, at kendskab til vandprøvernes saltholdighed er en forudsætning for en fyldestgørende bedømmelse af den kemiske sammensætning ud fra diagrammerne.

På tavle $\mathrm{I} a-b$ er vandanalyserne afbildet ved søjlediagrammer, der viser prøvernes procentiske indhold af $\mathrm{Ca}^{++}, \mathrm{Mg}^{++}$og $\mathrm{Na}^{+}+\mathrm{K}^{+}$samt $\mathrm{HCO}_{3}{ }^{-}$, $\mathrm{SO}_{4}^{--}$og $\mathrm{Cl}^{-}$.

På tavle II er vist et retvinklet diagram, hvori en vandanalyse afbildes ved et enkelt punkt med to sæt koordinater, henholdsvis $\left(\mathrm{Ca}^{++}+\mathrm{Mg}^{++}, \mathrm{HCO}_{3}^{-}+\right.$ $\left.\mathrm{CO}_{3}^{--}\right)$og $\left(\mathrm{Na}^{+}+\mathrm{K}^{+}, \mathrm{Cl}^{-}+\mathrm{SO}_{4}^{--}\right)$. Vandprøverne afbildet over den stiplede diagonal indeholder $\mathrm{NaHCO}_{3}$, hvis procentiske rkvivalentkoncentration angives ved den lodrette afstand fra punktet til diagonalen. Prøverne afbildet under diagonalen har permanent hårdhed, udtrykt ved den vandrette afstand fra punktet til diagonalen.

Tavle II omfatter endvidere to trekantsdiagrammer, der viser kationernes og anionernes sammensætning. Som i det retvinklede diagram er der til sammenligning indtegnet punkter, der repræsenterer havvand fra Kattegat ved Hirtsholmene. Endvidere er indtegnet rette linier, der rummer alle punkter med samme koncentrationsforhold som dette havvand, d.v.s. alle punkter med følgende forhold: $\mathrm{Ca}^{++}: \mathrm{Mg}^{++}=0,20, \mathrm{Ca}^{++}: \mathrm{Na}^{+}=0,04, \mathrm{Mg}^{++}: \mathrm{Na}^{+}=0,22$, $\mathrm{HCO}_{3}^{-}: \mathrm{SO}_{4}^{--}=0,05, \mathrm{Cl}^{-}: \mathrm{SO}_{4}^{--}=9,9$ og $\mathrm{HCO}_{3}^{-}: \mathrm{Cl}^{-}=0,005$. Dette medfører en opdeling af diagrammerne, der letter bedømmelsen af kationernes og anionernes koncentrationsforhold i vandprøverne sammenlignet med havvand.

Ud fra trekantsdiagrammerne kan foretages en direkte sammenligning af forhold som $\mathrm{Cl}^{-}: \mathrm{SO}_{4}{ }^{--}$samt $\mathrm{Ca}^{++}: \mathrm{Na}^{+}$og $\mathrm{Mg}^{++}: \mathrm{Na}^{+}$, der er af betydning for en bedømmelse af, om vandet har været underkastet henholdsvis sulfatreduktion og ionbytning. Afbildning i diagrammer som vist på tavle II giver endvidere mulighed for at bedømme, om der i et givet tilfælde kan foreligge rene blandinger af vandtyper af kendt sammensætning. Dette er betinget af det forhold, at tre vandprøver, hvoraf den ene udgør en blanding af de to andre, altid vil afbildes på en ret linie, ligesom en blanding af tre vandtyper vil afbildes inden for den trekant, der begrænses af de tre komponenter.

Vedrørende grafiske fremstillingsmetoders anvendelighed ved vurdering af vandanalyser kan henvises til J. D. HeM (1959). 


\begin{tabular}{|c|c|c|c|c|c|c|c|c|c|}
\hline $\begin{array}{l}\text { Arkiv nr. } \\
\text { file No. }\end{array}$ & $\begin{array}{c}\text { Dybde } \\
\text { depth } \\
\text { m }\end{array}$ & $\begin{array}{c}\text { Prøve vol. } \\
\text { sample vol. } \\
1\end{array}$ & $\begin{array}{c}\mathrm{HCO}_{3}^{-} \\
\mathrm{mg} / 1\end{array}$ & $\begin{array}{c}\mathrm{SO}_{4}^{--} \\
\mathrm{mg} / 1\end{array}$ & $\begin{array}{l}\mathrm{Cl}^{-} \\
\mathrm{mg} / \mathrm{l}\end{array}$ & $\begin{array}{c}\mathrm{Ca}^{++} \\
\mathrm{mg} / 1\end{array}$ & $\begin{array}{l}\mathrm{Mg}^{++} \\
\mathrm{mg} / 1\end{array}$ & $\begin{array}{c}\mathrm{Na}^{+}+\mathrm{K}^{+} \\
\text {ber.-calc. } \\
\quad \mathrm{mg} / 1\end{array}$ & $\begin{array}{l}\mathrm{Na}^{+} \\
\text {fl. fot. } \\
\mathrm{mg} / 1\end{array}$ \\
\hline 26.456 & $3,0-5,0$ & 5 & 256 & 107 & 28 & 116 & 0,4 & 32 & 17 \\
\hline - & $8,0-10,0$ & $\frac{1}{2}$ & 247 & 91 & 26 & 112 & 6,8 & 12 & 16 \\
\hline- & $14,0-20,0$ & 5 & 256 & 70 & 34 & 64 & 14 & 51 & 42 \\
\hline 27.113 & $18,5-20,0$ & 5 & 281 & 118 & 56 & 104 & 18 & 45 & 40 \\
\hline 27.115 & $11,5-13,0$ & 5 & 323 & 126 & 237 & 55 & 31 & 214 & 199 \\
\hline- & $18,5-20,0$ & 5 & 329 & 130 & 233 & 57 & 32 & 212 & 199 \\
\hline 27.112 & $13,5-15,0$ & $\frac{1}{2}$ & 201 & 123 & 259 & 86 & 25 & 157 & 164 \\
\hline- & $18,5-20,0$ & 5 & 201 & 111 & 256 & 79 & 25 & 156 & 154 \\
\hline - & $2,0-3,0$ & 5 & 482 & 342 & 366 & 116 & 36 & 381 & 369 \\
\hline 27.114 & $3,0-5,0$ & 5 & 268 & 188 & 656 & 99 & 53 & 402 & 385 \\
\hline- & $18,0-20,0$ & 5 & 488 & 366 & 2310 & 185 & 112 & 1433 & 1340 \\
\hline 27.118 & $18,0-20,0$ & $\frac{1}{2}$ & 525 & 11 & 106 & 4,2 & 3,5 & 260 & 250 \\
\hline 27.119 & $8,0-10,0$ & $\frac{1}{2}$ & 186 & 26 & 78 & 25 & 21 & 64 & 53 \\
\hline - & $13,0-15,0$ & $\frac{1}{2}$ & 183 & 4,5 & 78 & 21 & 22 & 56 & 51 \\
\hline- & $18,0-20,0$ & $\frac{1}{2}$ & 186 & 3,7 & 78 & 21 & 22 & 56 & 52 \\
\hline 27.117 & $25,0-27,0$ & $\frac{1}{2}$ & 250 & 29 & 352 & 33 & 42 & 218 & 205 \\
\hline- & $35,0-37,0$ & $\frac{1}{2}$ & 244 & 34 & 364 & 29 & 40 & 236 & 195 \\
\hline 27.103 & $9,75-11,25$ & $\frac{1}{2}$ & 500 & 31 & 688 & 22 & 27 & 573 & 575 \\
\hline 27.104 & $13,5-15,0$ & $\frac{1}{2}$ & 720 & 226 & 2580 & 52 & 81 & 1840 & 1863 \\
\hline 27.105 & $7,5-9,0$ & $\frac{1}{2}$ & 546 & 217 & 1660 & 32 & 51 & 1252 & 1220 \\
\hline- & $13,0-14,5$ & $\frac{1}{2}$ & 549 & 257 & 1990 & 41 & 73 & 1436 & 1430 \\
\hline 27.106 & $4,5-6,0$ & $\frac{1}{2}$ & 400 & 147 & 1615 & 40 & 79 & 1072 & 1038 \\
\hline 27.117 & $10,0-12,0$ & 5 & 1720 & 1,8 & 5020 & 146 & 269 & 3141 & 3000 \\
\hline- & $20,0-22,0$ & $\frac{1}{2}$ & 1693 & 0 & 4950 & 121 & 254 & 3229 & 3050 \\
\hline 26.454 & $8, \mathrm{C}-10,0$ & $\frac{1}{2}$ & 513 & 9,9 & 840 & 44 & 46 & 604 & 625 \\
\hline 27.103 & $19,5-20,0$ & $\frac{1}{2}$ & 482 & 147 & 1020 & 43 & 53 & 764 & 745 \\
\hline 27.107 & $18,0-21,5$ & $\frac{1}{2}$ & 406 & 32 & 1250 & 52 & 57 & 812 & 880 \\
\hline 26.455 & $11,5-13,5$ & 5 & 317 & 95 & 196 & 24 & 27 & 214 & 183 \\
\hline- & $18,0-20,0$ & 5 & 360 & 94 & 196 & 24 & 27 & 229 & 183 \\
\hline 26.454 & $3,0-5,0$ & 5 & 329 & 161 & 808 & 47 & 54 & 568 & 553 \\
\hline 27.107 & $8,5-10,0$ & $\frac{1}{2}$ & 391 & 391 & 1855 & $\ldots$ & $\ldots$ & 1325 & 1260 \\
\hline- & $13,5-15,0$ & $\frac{1}{2}$ & 409 & 214 & 1155 & $\ldots$ & $\ldots$ & 855 & 820 \\
\hline 27.116 & $13,0-20,0$ & 5 & 299 & 283 & 1260 & 46 & 67 & 887 & 836 \\
\hline 27.110 & $9,5-11,0$ & $\frac{1}{2}$ & 427 & 318 & 2000 & 63 & 96 & 1356 & 1313 \\
\hline 26.454 & $13,0-15,0$ & $\frac{1}{2}$ & 323 & 598 & 3720 & 82 & 188 & 2371 & 2200 \\
\hline- & $18,0-20,0$ & 5 & 329 & 616 & 3740 & 94 & 223 & 2316 & 2100 \\
\hline 27.111 & $8,5-10,0$ & 5 & 293 & 623 & 3260 & 116 & 174 & 2061 & 1950 \\
\hline 27.105 & $18,5-20,0$ & $\frac{1}{2}$ & 458 & 582 & 4360 & 109 & 245 & 2691 & 2530 \\
\hline 27.109 & $18,5-20,0$ & $\frac{1}{2}$ & 406 & 595 & 4400 & 127 & 244 & 2686 & 2425 \\
\hline 27.111 & $3,5-5,0$ & $\frac{1}{2}$ & 284 & 784 & 4020 & 134 & 243 & 2477 & \\
\hline - & $18,5-20,0$ & 5 & 293 & 1092 & 6050 & 193 & 370 & 3636 & 3700 \\
\hline 27.110 & $14,5-16,0$ & $\frac{1}{2}$ & 384 & 1096 & 6850 & 200 & 403 & 4121 & 4100 \\
\hline- & $18,5-20,0$ & 5 & 372 & 1128 & 6700 & 217 & 396 & 4029 & 4100 \\
\hline 27.108 & $3,5-5,0$ & $\frac{1}{2}$ & 445 & 1196 & 8700 & 257 & 533 & 5080 & 4750 \\
\hline- & $8,5-10,0$ & $\frac{1}{2}$ & 506 & 1223 & 8850 & 257 & 525 & 5230 & 4800 \\
\hline 27.109 & $8,5-10,0$ & $\frac{1}{2}$ & 500 & 1284 & 9950 & 304 & 601 & 5773 & 5660 \\
\hline- & $13,5-15,0$ & $\frac{1}{2}$ & 506 & 1300 & 10100 & 307 & 603 & 5871 & 5650 \\
\hline 26.454 & $22,5-40,0$ & $\frac{1}{2}$ & 293 & 1704 & 11200 & 375 & 762 & 6320 & 6250 \\
\hline 27.106 & $10,0-11,5$ & $\frac{1}{2}$ & 268 & 1663 & 11850 & 333 & 800 & 6688 & 6200 \\
\hline- & $18,5-20,0$ & $\frac{1}{2}$ & 235 & 1626 & 11600 & 341 & 776 & 6531 & 6200 \\
\hline 27.108 & $13,5-15,0$ & $\frac{1}{2}$ & 238 & 1939 & 14400 & 347 & 904 & 8249 & 7600 \\
\hline 27.104 & $18,5-20,0$ & $\frac{1}{2}$ & 408 & 1251 & 6950 & 454 & 451 & 3886 & 3780 \\
\hline \multicolumn{2}{|c|}{ Havv, - sea-water* } & $\ldots$ & 140 & 2390 & 17436 & 383 & 1159 & 9863 & $\ldots$ \\
\hline
\end{tabular}
a) $\mathrm{NO}_{3}^{-}: \quad 0 \mathrm{mg} / \mathrm{l}$
b) $\mathrm{NO}_{3}^{-}: \quad 0 \mathrm{mg} / 1$
e) $\mathrm{H}_{2} \mathrm{~S}$ : tilstede - present
h) $\mathrm{NO}_{3}^{-}$:
$0 \mathrm{mg} / \mathrm{l}$
c) $\mathrm{CO}_{2}$ (fri): $0 \mathrm{mg} / \mathrm{l}$
$\mathrm{NO}_{2}^{-}: \quad 0 \mathrm{mg} / \mathrm{l}$
d) $\mathrm{NO}_{3}{ }^{-}: \quad 0 \mathrm{mg} / 1$
g) $\mathrm{CO}_{2}$ (fri): $0 \mathrm{mg} / 1$
*) Fra Kattegat ved Hirtsholmene - from the Kattegat at Hirtsholmene (H. ØDuM og WR. Christensen, 1936, p. 75). 
Water Analyses

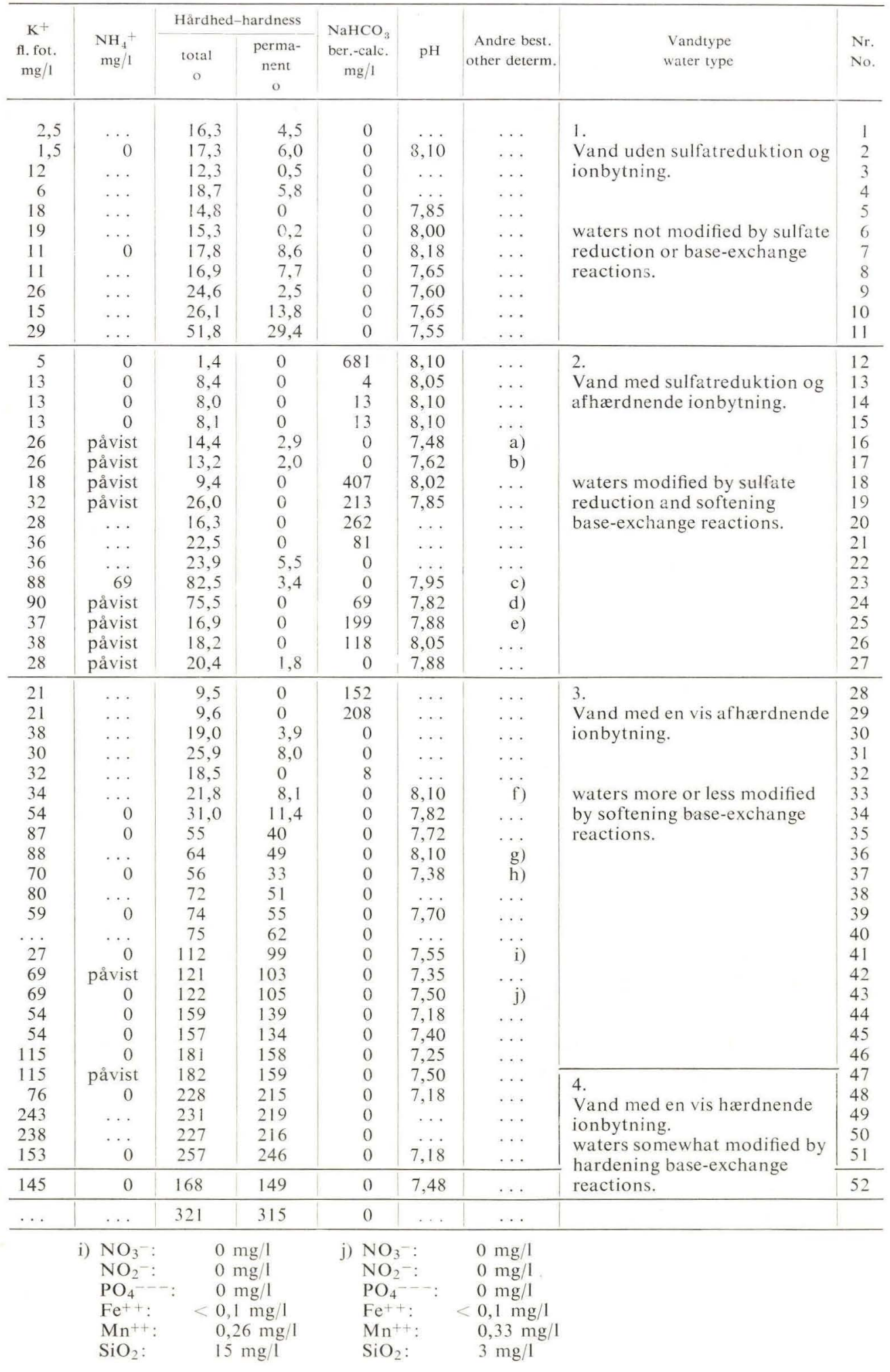


På grundlag af vandprøvernes sammensætning er opstillet 4 vandtyper. Inddelingen af prøverne i disse typer er dog ikke eentydig; i en del tilfælde beror det på et skøn, hvilken vandtype en prøve må henføres til. Vandtyperne karakteriseres ved følgende egenskaber.

1. Vand uden sulfatreduktion og ionbytning. Denne vandtype omfatter overvejende ferskvand med en saltholdighed, der ligger under smagsgrænsen, d.v.s. ca. $400 \mathrm{mg} \mathrm{Cl}-/ 1$. Prøvernes forholdsvis store indhold af $\mathrm{SO}_{4}^{--}, \mathrm{Ca}^{++}$og $\mathrm{Mg}^{++}$tyder på, at sulfatreduktion og ionbytning ikke har fundet sted. Vand af denne type indeholder ikke $\mathrm{NaHCO}_{3}$. Prøverne fra bor. 27.115 har udelukkende forbigående hårdhed; de øvrige prøver har desuden varierende permanent hårdhed.

2. Vand med sulfatreduktion og afhardnende ionbytning. Vandtypen omfatter både ferskvand og saltvand. Vandet karakteriseres ved forholdsvis lavt sulfatindhold og ringe hårdhed. Et flertal af prøverne indeholder $\mathrm{NaHCO}_{3}$; enkelte har dog ubetydelig permanent hårdhed. $\mathrm{NH}_{4}{ }^{+}$optræder hyppigt.

Af tavle II fremgår, at forholdet $\mathrm{Cl}^{-}: \mathrm{SO}_{4}{ }^{--}$med enkelte undtagelser er større end det tilsvarende forhold for havvand. Vandet må derfor antages at have været underkastet sulfatreduktion, idet reduktionsgraden dog er varierende. Endvidere bemærkes, at forholdene $\mathrm{Ca}^{++}: \mathrm{Na}^{+}$og $\mathrm{Mg}^{++}: \mathrm{Na}^{+}$for en del prøvers vedkommende er mindre end for havvand, samt at disse forhold ikke varierer eentydigt med saltholdigheden. Dette må være en følge af ionbytningsprocesser, hvorved en del af vandets $\mathrm{Ca}^{++}$og $\mathrm{Mg}^{++}$er ombyttet med $\mathrm{Na}^{+}$fra sedimenternes lerpartikler. Ionbytningsgraden er som reduktionsgraden varierende. Vedrørende en mere indgående behandling af sulfatreduktion og ionbytning i danske grundvandstyper henvises til H. ØDum og WR. Christensen, 1936.

3. Vand med en vis af hardnende ionbytning. Denne vandtype omfatter cå godt som udelukkende saltvand. Prøvernes sulfatindhold giver ikke grund til at antage, at sulfatreduktion har fundet sted. De mindre saltholdige vandprøver synes derimod at være påvirket af ionbytningsprocesser, hvorved en del af vandets $\mathrm{Ca}^{++}$og $\mathrm{Mg}^{++}$er ombyttet med $\mathrm{Na}^{+}$. Med stigende saltholdighed bliver dette træk mindre fremtrædende, og vandet får gradvist karakter af havvand.

4. Vand med en vis hardnende ionbytning. Vandtypen er kun repræcerteret ved en enkelt prøve af saltvand. Trods en saltholdighed på $6950 \mathrm{mg} \mathrm{Cl}-/ 1 \mathrm{er}$ forholdet $\mathrm{Ca}^{++}: \mathrm{Na}^{+}$ca. 3 gange så stort som for havvand, medens forholdet $\mathrm{Mg}^{++}: \mathrm{Na}^{+}$er af samme størrelsesorden som for havvand. Vandets betydelige indhold af $\mathrm{Ca}^{++}$kan være en følge af ionbytningsprocesser, der i modsætning til den før omtalte ionbytning har resulteret i, at en del af vandets $\mathrm{Na}^{+}$er ombyttet med $\mathrm{Ca}^{++}$fra sedimenternes lerpartikler. 


\section{Områdets hydrologiske forhold}

De opstillede vandtyper afspejler forskellige geokemiske miljøforhold. De optræder med en vis geografisk fordeling, der fremgår af fig. 6, p. 40.

Ferskvand uden sulfatreduktion og ionbytning optræder ved Kristianshåb. Vand af denne type har næppe været i kontakt med de marine, lerholdige sedimenter af sen- eller postglacial alder, der er konstateret i Kristianshåbområdet. I området nordøst herfor kan der ifølge de geoelektriske måleresultater derimod ikke forventes ler af betydning i de øvre jordlag, og vandprøvernes sammensætning sammenholdt med områdets terrænforhold (se fig. 1, p. 8), giver derfor grund til at antage, at der i Kristianshåb-området hersker en mod syd eller sydvest rettet bevægelse af fersk grundvand. Ved Kristianshåb er ferskvandet kun i uvæsentlig grad opblandet med saltvand. Derimod er vandet fra den mere kystnære bor. 27.114 betydeligt mere saltholdigt, sandsynligvis som følge af opblanding med indtrængende fjordvand.

I denne forbindelse kan nævnes, at balancedybden mellem ferskvand og fjordvand ved hydrostatiske trykforhold efter BADON GHIJEen's lov $\mathrm{D}=\mathrm{p}$ : (d - 1) kan beregnes til at ligge mellem kote $\div 44 \mathrm{~m}$ og $\div 112 \mathrm{~m}$ for boringerne $26.455,26.456,27.112,27.113$ og 27.115 , idet vandrejsningen i disse boringer er $0,7 \mathrm{~m}$ under terræn, og terrænkoten er mellem $+1,57 \mathrm{~m}$ og $+3,14 \mathrm{~m}$ (se fig. 1 , p. 8). $(\mathrm{D}=$ balancedybden, $\mathrm{p}=$ ferskvandspotentialet $=$ vandrejsningen $\mathrm{og}$ $\mathrm{d}=$ saltvandets vægtfylde; $\mathrm{d}$ sættes lig med 1,02 efter H. ØDum og WR. CHRISTENSEN, 1936, p. 68). For de øvrige boringers vedkommende viser tilsvarende beregninger, at den teoretiske balancedybde må ligge over kote $\div 54 \mathrm{~m}$, for bor. 27.111 endog over kote $\div 44 \mathrm{~m}$. Terrænkoten er for disse boringer mindre end $+1,57 \mathrm{~m}$; vandrejsningen er i bor. $27.1110,7 \mathrm{~m}$ under terræn, i de øvrige boringer $0,5 \mathrm{~m}$ under terræn.

Vand med sulfatreduktion og afhærdnende ionbytning optræder fortrinsvis $i$ den østlige del af Stranden-området og i Vester Hasing enge. Den afhærdnende ionbytning må være en følge af vandets kontakt med de sen- eller postglaciale lerholdige sedimenter. Sulfatreduktionen må i visse tilfælde, f. eks. i prøverne fra bor. 27.117 og 27.106, antages at være et resultat af vandets passage gennem humøse, postglaciale aflejringer. Hvor det sulfatreducerede vand optræder i tilknytning til forekomster af senglacialt ler, kan reduktionen muligvis stå i forbindelse med, at der under disse lerlag lokalt kan herske et stagnerende miljø som følge af lerets uregelmæssige lejringsforhold. Således synes sulfatreduktionen i boringerne 27.103-105 fortrinsvis at være knyttet til de sandlag, der begrænses af henholdsvis det senglaciale ler og det dybere liggende lerlag. Vandprøvernes forskelligartede sammensætning med varierende reduktionsgrad og ionbytningsgrad er iøvrigt i god overensstemmelse med, at der i denne del af området må forventes stærkt lokalt prægede miljøforhold som følge af tilstedeværelsen af een eller flere lerhorisonter.

Prøverne repræsenterer vekslende blandinger af ferskvand og saltvand. Ned- 
sivningen i denne del af området må anses for at være uvæsentlig, og den ringe saltholdighed i vandprøverne fra bor. 27.118 og 27.119 samt fra den nedre sandhorisont i bor. 27.117 må stå i forbindelse med en mod syd eller sydvest rettet bevægelse af ferskvand. Det bemærkes, at prøvernes saltholdighed gennemgående er mindre end i prøverne fra den vestlige del af Stranden-området og fra Kristianshåb strandenge, hvilket kan tyde på, at indtrængningen af fjordvand hæmmes som følge af lerlagenes tilstedeværelse. Da der som før nævnt i nogle tilfælde synes at herske stagnerende forhold, foreligger der mulighed for tilstedeværelse af fossilt havvand af postglacial, eventuelt også af senglacial oprindelse. Det kan dog ikke på nuværende tidspunkt afgøres, i hvilken udstrækning prøvernes saltholdighed er en følge af opblanding med henholdsvis recent eller fossilt havvand.

Vand med en vis afhærdnende ionbytning optræder $i$ den vestlige del af Stranden-området og i Kristianshåb strandenge. Denne vandtype antages at repræsentere vekslende blandinger af ionbyttet ferskvand og saltvand. Saltholdigheden er størst i prøverne fra de mest kystnære boringer og stiger for de fleste boringers vedkommende med dybden. Prøvernes sammensætning tyder ikke på stagnerende forhold, og det antages, at saltholdigheden i overvejende grad skyldes opblanding med recent fjordvand. At saltholdigheden i bor. 27.109 er størst i de øvre jordlag kan stå i forbindelse med, at der under oversvømmelser vil ske en nedsivning af fjordvand, hvor der ikke optræder vandstandsende lerlag.

Den fjerde vandtype synes påvirket af ionbytningsreaktioner mellem saltvand og ferskvandsler. Den er kun truffet i bor. 27.104 og synes ikke at optræde almindeligt i området.

Området kan sammenfattende karakteriseres ved ret varierende grundvandskemiske forhold. Dette må anses for at være en følge af forskelligartede kemiske og fysiske størrelser som redoxniveau, permeabilitets- og potentialforhold med relation til områdets uensartede geologiske opbygning. De fremkomne resultater kan iøvrigt tjene som eksempel på, at enkelte vandanalyser fra et område kan give ufuldstændige oplysninger om grundvandsforholdene. 


\section{DEN GEOELEKTRISKE KORTLÆGNING}

\section{Jordarternes elektriske modstand}

En jordarts modstandsforhold kan karakteriseres ved formationsfaktoren $\mathrm{F}=\rho_{\mathrm{o}} / \rho_{\mathrm{v}}$, hvor $\rho_{\mathrm{o}}$ er jordartens specifike modstand, når den er mættet med væske, hvis specifike modstand er lig med $\rho_{\mathrm{v}}$. For jordarter uden ledende faste partikler vil formationsfaktoren være en for den enkelte jordart karakteristisk konstant, der bestemmes af de fysiske egenskaber som porøsitet og permeabilitet. Ved tilstedeværelse af ler påvirkes modstanden af lerindholdet, hvilket medfører, at formationsfaktoren for en given lerholdig jordart ikke er konstant men varierer med porevandets specifike modstand. En mere indgående behandling af jordlagenes elektriske modstand er f. eks. foretaget af C. A. Heiland (1951) og J. W. Amyx, D. M. Bass og R. L. Whiting (1960).

\section{Lerlagenes modstand}

Der synes at herske en del usikkerhed angånde de ovennævnte faktorers relative indflydelse på lerlags elektriske modstand. På grundlag af modstandsmålinger på intakte prøver opfatter PATNOdE og WylLie (1950) en given jordarts totale ledningsevne som summen af væskefasens ledningsevne og den faste fases ledningsevne, idet sidstnævnte antages at være konstant, uafhængig af porevandets sammensætning. Ud fra lignende målinger påviser HıLL og MILBURN (1956) imidlertid, at lerfraktionens ledningsevne varierer med porevandets sammensætning og iøvrigt kan sættes i relation til prøvens »effektive lerindhold « udtrykt ved kationombytningskapaciteten pr. porevolumenenhed.

HiLl's og MilburN's antagelse af en mere kompliceret sammenhæng mellem lerindhold og specifik modstand er i bedst overensstemmelse med det forhold, at ler må opfattes som et dynamisk system, hvis elektrokemiske og fysiske tilstand varierer med det kemiske miljø. Ifølge RosenQvist (1955, p. 51) må ler antages at bestå af aggregater af lermineraler og kationer, der kun i ringe grad er dissocieret, idet dissociationsgraden og dermed lerpartiklernes negative ladning varierer med porevandets elektrolytindhold. ROSENQVIST har således beregnet, at dissociationsgraden i salt marint ler er under $0,2 \%$, medens den i udvasket marint ler (kvikler) er ca. $3 \%$. De elektrokemiske forhold har afgørende indflydelse på lerets mekaniske egenskaber (RosenQvisT, 1955), porøsitet og permeabilitet (Tovborg Jensen, 1955, Aslyng, 1955, Engelhardt, 1960). Det må hertil antages, at de elektrokemiske forhold også har betydning for lerets elektriske modstand. 
Det foreliggende materiale tillader ikke vurdering af lerfraktionens indflydelse på lerlagenes specifike modstand, idet de værdier for lerfraktionens bidrag til leropslæmningernes ledningsevne, der kan beregnes ud fra ler- og sandopslæmningernes specifike modstand (se pp. 31-33), kun gælder for de pågældende forsøgsbetingelser. Det må imidlertid antages, at leropslæmningernes modstandsforhold kvalitativt afspejler de intakte lerlags modstandsforhold. Disse udviser under denne forudsætning følgende generelle træk.

Den specifike modstand i ler er lavere end i sand med porevand af samme sammensætning, ikke blot på grund af lerets større vandindhold, men også på grund af lerfraktionens ledningsevne. Lerets modstand må variere med lerfraktionens størrelse og mineralselskab og med et eventuelt indhold af andre ledende faste partikler. Den må for de her forekommende lertyper antages at aftage i rækkefølgen: moræneler, forvitret ler, fedt ler, humøst ler og dynd. Den enkelte lertypes modstandsniveau må iøvrigt variere med porevandets sammensætning; der må dog forventes en ret kompliceret sammenhæng mellem disse to størrelser, da det som før omtalt må antages, at både væskefasens og den faste fases ledningsevne varierer med porevandets elektrolytindhold.

En oversigt over forskellige danske aflejringers specifike modstand, beregnet ud fra geoelektriske måleresultater, er udarbejdet af SoRGENFreI (1955, p. 78).

\section{Sandlagenes modstand}

Den specifike modstand i lerfrie sandlag kan med tilnærmelse beregnes ud fra porevandets mængde og sammensætning, idet formationsfaktorens afhængighed af porøsitet og andre fysiske størrelser er undersøgt såvel eksperimentelt som ved teoretiske beregninger. Eksempelvis har MAXWELL beregnet ledningsevnen for et aggregat af kugleformede korn, opbygget således, at kornenes afstand er stor i forhold til deres radius. På grundlag af disse beregninger har Sundberg (se HeILAND, 1951, p. 636) afbildet formationsfaktorens afhængighed af porøsiteten; kurveforløbet fremgår af fig. 7 .

Modstande beregnet ud fra denne kurve skulle efter HeILAND være i god overensstemmelse med modstande målt på intakte prøver. I det følgende benyttes kurven til at bedømme lerfrie sandlags modstandsforhold ud fra kendskab til lagenes porøsitet og porevandets specifike modstand.

Porøsitet. Enkelte bestemmelser af porøsiteten i tæt pakkede sandprøver fra intervallerne bor. $27.106(4,5-6,0 \mathrm{~m})$ samt bor. $27.107(8,5-10,0 \mathrm{~m})$ har givet værdier på 27-32\%. Til sammenligning kan nævnes, at porøsiteten i forskellige danske jordarter, både sand- og lerholdige, ifølge V. MiLthers (1903) varierer mellem $25 \%$ og $50 \%$. Endvidere nævner W. v. ENGELhardt (1960, pp. 14-16), at recente sandsedimenter fra Nordsøen med en kornstørrelse på 0,12-0,25 mm har en porøsitet på $40-45 \%$, samt at der for løs sandsten (Valanginien og 


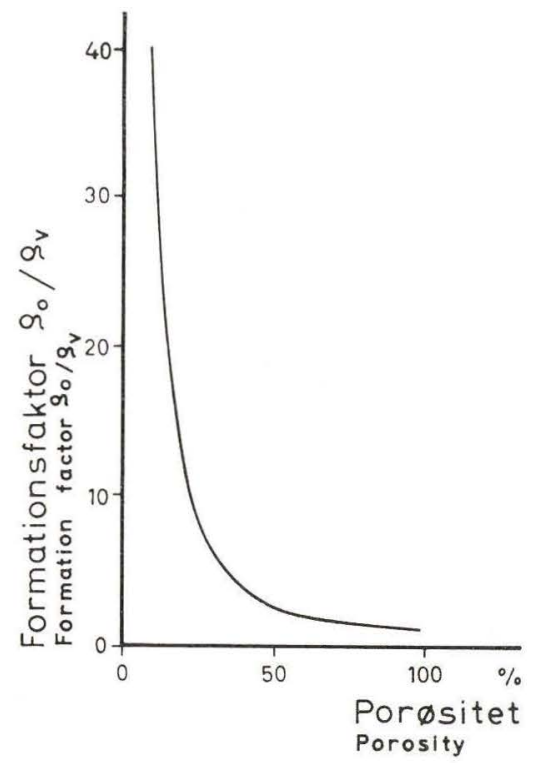

LEGEND :

S. aggregatets specifike modstand

resistivity of aggregate

$S_{v}$ porevandets specifike modstand

resistivity of interstitial water

Fig. 7. Aggregat af ikke ledende, kugleformede korn. Relation mellem formationsfaktor $\rho_{\mathrm{o}} / \rho_{\mathrm{v}}$ og porøsitet (efter SUNDBERG).

Aggregate of non conductive spherical solids. Formation factor $\rho_{\mathrm{o}} / \rho_{\mathrm{V}}$ related to porosity (after SundBerg).

Lias $\alpha$ ) fra tyske oliefelter (842-1483 m dybde) er bestemt porøsiteter på 23$33 \%$. Ud fra disse oplysninger må det antages, at porøsiteten for sandlagene in situ i det her undersøgte område ligger i intervallet $25-45 \%$.

Porevandets specifike modstand. Angivelserne af porevandets specifike modstand er baseret på ledningsevnemålinger i opløsninger, der blev fremstillet på grundlag af nogle af vandanalyserne*). Det blev samtidig undersøgt, med hvilken tilnærmelse grundvandets specifike modstand kan bedømmes ud fra oplysninger om dets saltholdighed sammenholdt med kendskab til rene $\mathrm{NaCl}$ opløsningers modstandsforhold.

Den specifike modstand bestemtes dels på opløsninger af saltene $\mathrm{CaCl}_{2}$. $6 \mathrm{H}_{2} \mathrm{O}, \mathrm{MgCl}_{2} \cdot 6 \mathrm{H}_{2} \mathrm{O}, \mathrm{NaHCO}_{3}, \mathrm{Na}_{2} \mathrm{SO}_{4}$ og $\mathrm{NaCl}$ fremstillet ud fra de $\mathrm{i}$ vandanalyserne angivne koncentrationer af $\mathrm{Cl}^{-}, \mathrm{HCO}_{3}^{--}, \mathrm{SO}_{4}^{--}, \mathrm{Ca}^{++}, \mathrm{Mg}^{++}$

*) Direkte bestemmelser af vandprøvernes ledningsevne kunne ikke foretages, da vandprøverne ikke var opbevaret ved undersøgelsen af boreprøverne. 


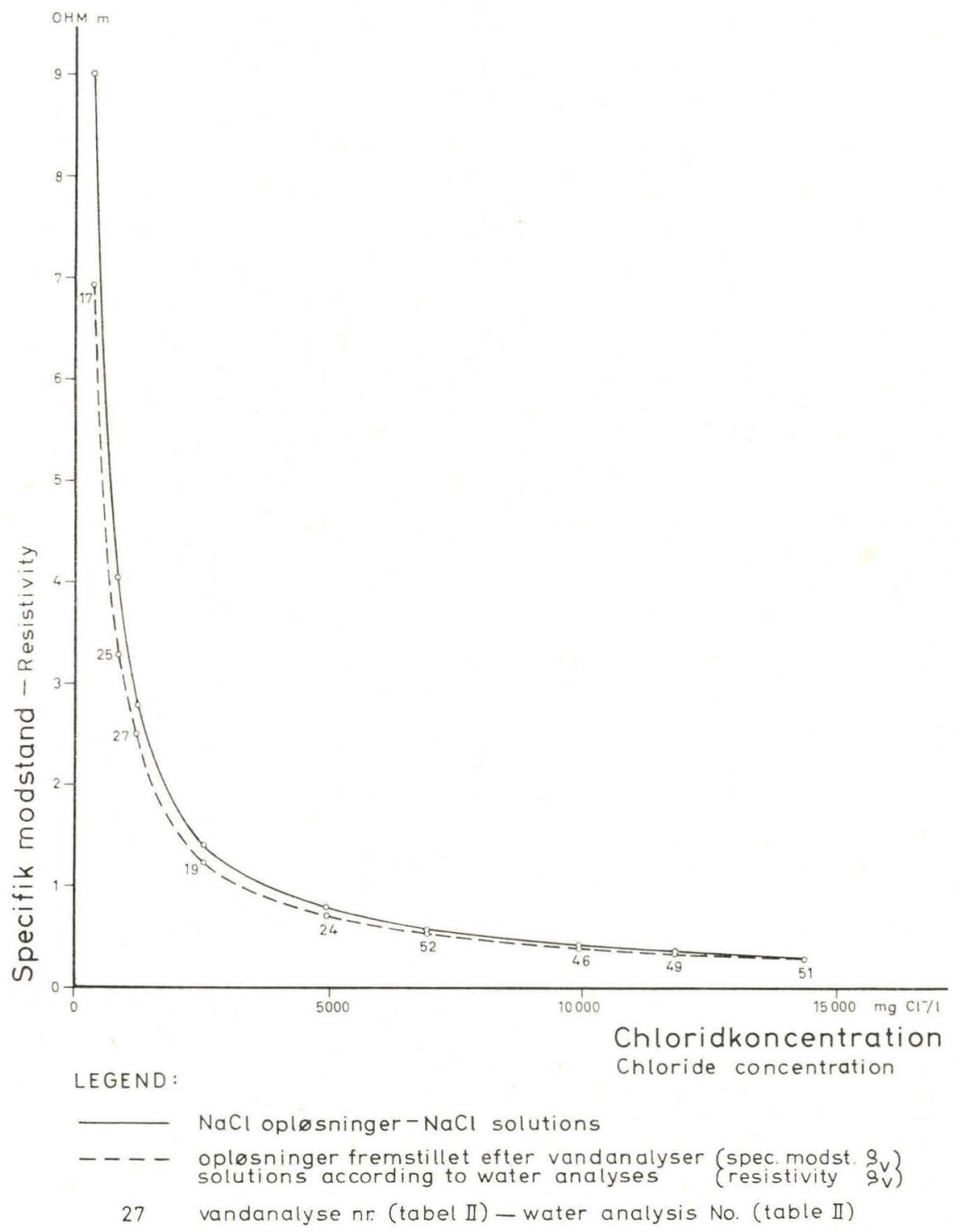

Fig. 8. Saltopløsningernes specifike modstand i forhold til deres chloridkoncentration.

Resistivity of salt solutions related to chloride concentration.

og $\mathrm{Na}^{+}$, og dels på $\mathrm{NaCl}$-opløsninger fremstillet ud fra de i samme vandanalyser angivne koncentrationer af $\mathrm{Cl}^{-}$. Opløsningernes specifike modstand er i fig. 8 afbildet som funktion af chloridkoncentrationen.

Af fig. 8 ses, at den fejl, der begås ved at bedømme grundvandets specifike modstand ud fra dets chloridkoncentration, vokser med aftagende saltholdighed. I ferskvand kan der ikke forventes relation mellem specifik modstand og chlorid- 


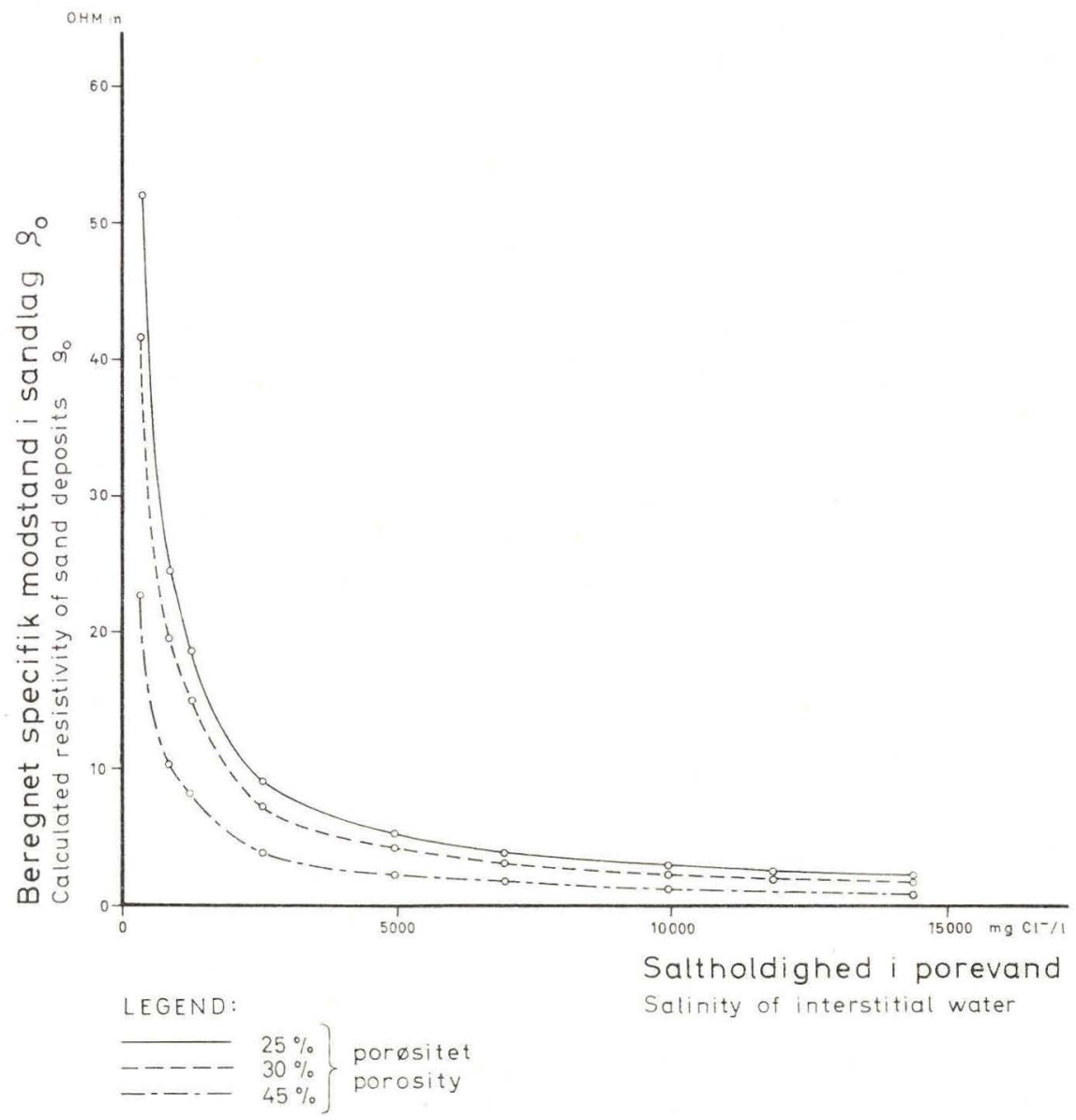

Fig. 9. Sandlag uden ledende mineralkorn. Beregnet specifik modstand i forhold til porevandets saltholdighed.

Sand deposits without conductive solids. Calculated resistivity related to salinity of interstitial water.

koncentration, da modstanden her i vid udstrækning bestemmes af vandets indhold af andre ioner.

Sandlagenes specifike modstand. Modstandsforholdene kan bedømmes ud fra kurverne i fig. 7 og 8 . For en given porøsitet aflæses i fig. 7 en værdi for $\rho_{\mathrm{o}} / \rho_{\mathrm{v}}$, ved hjælp af hvilken $\rho_{\mathrm{o}}$ kan beregnes ud fra $\rho_{\mathrm{v}}$-værdier i fig. 8.

Fig. 9 viser, hvorledes sandets specifike modstand aftager med stigende saltholdighed i porevandet. I denne forbindelse kan nævnes, at den specifike modstand for moræneler ifølge geoelektriske måleresultater er af størrelsesordenen 40-50 OHMm, medens den for senglacialt yoldialer er under $10 \mathrm{OHMm}$. Under forudsætning af, at sandlagene har en porøsitet på ca. $30 \%$ og ikke indeholder ler eller organisk materiale, vil de således ifølge fig. 9 vise en spe$4 *$ 
cifik modstand af samme størrelsesorden som det senglaciale ler, når porevandets saltholdighed overskrider ca. $2000 \mathrm{mg} \mathrm{Cl}-/ 1$; for lerholdige og humøse sandlag vil den kritiske værdi for porevandets saltholdighed ligge lavere. Sammenholdes dette med de foreliggende oplysninger om områdets grundvandsforhold, vil det fremgå, at sandlagene i vid udstrækning må vise samme eller lavere modstand end lerlagene.

\section{Punktprofilerne}

Den geoelektriske undersøgelse i området indledtes som nævnt p. 9 med linieprofilopmålinger med en elektrodeafstand på henholdsvis 10 og 20 m. Punktprofilopmålingerne og de tilhørende boringer udførtes med enkelte undtagelser på arealer, der omskrives af 10 OHMm kurverne (se fig. 6, p. 40). Boringerne viste, at der i disse områder optræder lerlag eller saltvandsførende sandlag.

Resultatet af punktprofilopmålingerne er afbildet på tavle Ia-b, idet de enkelte punkter i punktprofilkurven angiver den gennemsnitlige specifike modstand for samtlige jordlag ned til den pågældende dybde, svarende til elektrodeafstanden. Målingerne med en elektrodeafstand større end de tilhørende boringers dybde er dog ikke medtaget. De enkelte jordlags specifike modstand og mægtighed kan beregnes ved at sammenholde punktprofilkurven, afbildet $\mathrm{i}$ et dobbeltlogaritmisk koordinatsystem, med kurveskarer, der er baseret på teoretiske beregninger af Hedström (se Sorgenfrei, 1955, pp. 15-19). De opstillede kurveskarer forudsætter planparallelle, horisontale lagflader med en udstrækning, der er større end $5 \mathrm{a} \cdot 5 \mathrm{a}$, hvor a er elektrodeafstanden. Usikkerheden ved fastlæggelsen af laggrænser ud fra punktprofilkurver vokser iøvrigt med dybden og med aftagende lagtykkelse. De enkelte jordlags beregnede specifike modstand og mægtighed er anført i tabel III*).

Jordlagene over grundvandsspejlet udviser gennemgående relativt høje modstandsværdier; modstanden varierer med sedimenttypen og må i vid udstrækning være bestemt af lagenes indhold af vadost vand. For jordlagene under grundvandsspejlet varierer punktprofilkurvernes forløb med de geologiske og de grundvandskemiske forhold. Disse kan sammenfattes i de geohydrologiske situationer, der behandles i det følgende.

Ler underlejret af ferskvandsforende sand træffes i boringerne 26.455, 26.456, $27.112,27.113,27.115,27.118$ og 27.119. De tilhørende punktprofiler viser et karakteristisk minimum. Modstanden varierer iøvrigt med lerets saltholdighed, idet de øvre jordlag har forholdsvis stor indflydelse på kurveforløbet.

Ved alle punktprofilerne optræder intervaller med forholdsvis lav specifik modstand, ca. 10 OHMm og derunder (se tabel III). Disse modstandsværdier er antagelig betinget af lerforekomsterne. Den geofysiske laggrænse ligger gennemgående i større dybde end grænsen mellem ler og sand, hvorfor bedømmel-

\footnotetext{
*) Beregningerne er udfort af Th. SORGENFret og N. V. JeSSEN.
} 
Punktprofiler. Beregnet specifik modstand

Tabel III

Resistivity Sounding. Calculated Resistivity

\begin{tabular}{|c|c|c|c|c|c|c|c|c|c|}
\hline $\begin{array}{l}\text { Arkiv nr. } \\
\text { file No. }\end{array}$ & $\begin{array}{l}\text { Dybde } \\
\text { depth }\end{array}$ & & $\begin{array}{r}\text { Specifik } \\
\text { resi }\end{array}$ & $\begin{array}{l}\text { modstand } \\
\text { istivity }\end{array}$ & $\begin{array}{l}\text { Arkiv nr. } \\
\text { file No. }\end{array}$ & $\begin{array}{l}\text { Dybde } \\
\text { depth }\end{array}$ & & $\begin{array}{r}\text { Specifik } \\
\text { resis }\end{array}$ & $\begin{array}{l}\text { modstand } \\
\text { istivity }\end{array}$ \\
\hline 26.455 & $0-0,10$ & $\mathrm{~m}$ & 145 & $\mathrm{OHMm}$ & 27.114 & $0-0,65$ & $\mathrm{~m}$ & 290 & $\mathrm{OHMm}$ \\
\hline & $0,10-0,18$ & - & 16,0 & - & & $0,65-5,2$ & - & 32 & - \\
\hline & $0,18-0,76$ & & 20,8 & - & & $5,2-15,0$ & - & 19,0 & - \\
\hline & $0,76-4,4$ & & 5,5 & - & & $15,0-20$ & & 28,0 & - \\
\hline & $4,4-5,5$ & - & 2,1 & - & & & & & \\
\hline & $5,5-15,0$ & - & 8,7 & - & 26.454 & $0-0,19$ & - & 15,5 & - \\
\hline & $15,0-53$ & - & 37,4 & - & & $0,19-0,29$ & - & 23,2 & - \\
\hline 26.456 & $0-0,23$ & - & 23,0 & - & & $0,29-1,15$ & - & 7,3 & - \\
\hline & $0,23-0,36$ & - & 12,4 & - & & $\begin{array}{l}1,15-2,8 \\
2,8\end{array}$ & - & 25,8 & - \\
\hline & $0,36-1,05$ & - & 26,3 & - & & $2,8-9,0$ & - & 26,0 & - \\
\hline & $1,05-1,25$ & - & 4,1 & - & & 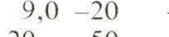 & - & 14,0 & - \\
\hline & $1,25-4,0$ & - & 8,4 & - & & $20-50$ & - & 4,0 & - \\
\hline & $4,0-4,7$ & - & 3,1 & - & 27.103 & $0-0,29$ & - & 21,0 & - \\
\hline & $4,7-8,5$ & - & 5,9 & - & & $0,29-0,56$ & - & 25,6 & - \\
\hline & $8,5-19,0$ & - & 4,4 & - & & $0,56-1,3$ & - & 7,7 & - \\
\hline & $19,0-(40)$ & - & 15,6 & - & & $1,3-6,4$ & - & 5,9 & - \\
\hline 27.112 & $0-0,13$ & - & 51 & - & & $6,4-15,0$ & & 9,9 & - \\
\hline & $0,13-0,27$ & - & 41,8 & - & & $15,0-72$ & - & 6,6 & - \\
\hline & $0,27-2,7$ & - & 85,5 & - & 27.104 & $0-0,17$ & $1-$ & 28,5 & - \\
\hline & $2,7-20$ & - & 8,6 & - & & $0,18-0,21$ & - & 7,1 & - \\
\hline & $20-50$ & - & 190 & - & & $0,21-0,54$ & - & 11,4 & - \\
\hline 27.113 & $0-0,19$ & - & 64 & - & & $0,54-2,0$ & - & 3,9 & - \\
\hline & $0,19-0,23$ & - & 34,6 & - & & $2,0-12,0$ & - & 7,1 & - \\
\hline & $0,23-0,66$ & - & 40,5 & - & & $12,0-27,5$ & - & 4,5 & - \\
\hline & $0,66-0,72$ & - & 23,8 & - & 27.105 & $0-0,30$ & - & 13,2 & - \\
\hline & $0,72-1,7$ & - & 27,5 & - & & $0,30-1,15$ & - & 4,4 & - \\
\hline & $1,7-19,5$ & - & 3,5 & - & & $1,15-1,9$ & - & 15,6 & - \\
\hline & $19,5-39$ & - & 35,1 & - & & $1,9-3,9$ & - & 10,5 & - \\
\hline 27.115 & $0-0,38$ & - & ca. $100-35$ & - & & $3,9-8,5$ & - & 15,8 & - \\
\hline & $0,38-1,15$ & - & 23,5 & - & & $\begin{array}{r}8,5 \\
-14,0\end{array}$ & - & 7,8 & - \\
\hline & $1,15-4,7$ & - & 2,9 & - & & $14,0-60$ & - & 3,2 & - \\
\hline & $4,7-17,5$ & - & 5,7 & - & 27.106 & $0-0,27$ & - & 17,0 & - \\
\hline & $17,5-57$ & - & 45,9 & - & & $0,27-1,65$ & - & 5,7 & - \\
\hline 27.118 & $0-0,40$ & - & 24,0 & - & & $1,65-3,9$ & - & 19,2 & - \\
\hline & $0,40-1,10$ & - & 2,0 & - & & $3,9-9,0$ & - & $\begin{array}{r}15,8 \\
70\end{array}$ & - \\
\hline & $1,10-5,7$ & - & 4,0 & - & & $\begin{array}{r}9,0-16,5 \\
16-53\end{array}$ & ${ }^{-}$ & 7,0 & - \\
\hline & $5,7-13,0$ & - & 32,0 & - & & 16,5 -ca. 42 & $2-$ & 1,1 & - \\
\hline & $13,0-40$ & - & 63 & - & 27.107 & $0-0,40$ & - & 60 & - \\
\hline 27.119 & $0-0,50$ & & 56 & & & $0,40-3,9$ & - & 7,0 & - \\
\hline & $0,50-1,0$ & - & 14,0 & - & & $3,9-12,5$ & - & 11,0 & - \\
\hline & $1,0-8,0$ & - & 10,0 & - & & $12,5-35$ & - & 9,0 & - \\
\hline & $8,0-68$ & - & 26,0 & - & 27.111 & $0-0,14$ & & 65 & - \\
\hline 27.109 & $0-0,29$ & - & 38 & - & & $0,14-0,15$ & - & 7,2 & - \\
\hline & $0,29-0,36$ & - & 9,5 & - & & $0,15-0,38$ & - & 9,2 & - \\
\hline & $0,36-1,0$ & - & 5,8 & - & & $0,38-1,75$ & - & 4,5 & - \\
\hline & $1,0-1,8$ & - & 9,8 & - & & $1,75-2,9$ & - & 20,8 & - \\
\hline & $1,8-6,2$ & - & 7,1 & - & & $2,9-4,8$ & - & 5,1 & - \\
\hline & $6,2-6,6$ & - & 1,9 & - & & $4,8-28$ & - & 5,2 & - \\
\hline & $6,6-17,5$ & - & 3,2 & - & 27.116 & $0-0,40$ & - & 15,0 & - \\
\hline & $17,5-38$ & - & 2,1 & - & & $0,40-2,4$ & - & 7,0 & - \\
\hline 27.110 & $0-0,39$ & - & 6,2 & - & & $2,4-8,0$ & - & 10,0 & - \\
\hline & $0,39-0,90$ & - & 4,2 & & & $8,0-58$ & - & 16,5 & - \\
\hline & $0,90-5,2$ & - & 7,4 & - & 27.117 & $0-0,15$ & - & 2,56 & - \\
\hline & $5,2-8,4$ & - & 3,0 & - & & $0,15-0,4$ & - & 7,7 & - \\
\hline & $8,4-14,0$ & - & 7,8 & - & & $0,4-2,8$ & - & 5,6 & - \\
\hline & $14,0-15,5$ & - & 2,2 & - & & $2,8-7,0$ & - & 2,4 & - \\
\hline & $15,5-30$ & - & 5,4 & - & & $7,0-34$ & - & 7,0 & - \\
\hline
\end{tabular}


sen af lerets mægtighed er behæftet med usikkerhed. I boringerne 26.455, 27.113, 27.115 og 27.119 ligger den geofysiske laggrænse 2-6 m under grænsen mellem ler og sand, for de øvrige boringer er afvigelsen større. Afvigelsen fremkommer antagelig ved, at laggrænserne ikke er horisontale, at de geoelektriske måleresultater er påvirket af de horisontale variationer i de geologiske og hydrologiske forhold, samt at de underliggende sandsedimenter kan indeholde lerlag. Eksempelvis kan de lave modstandsværdier i punktprofil 26.456 skyldes, at strømlinieforløbet er påvirket af nærliggende forekomster af ler.

Saltvandsførende sand. Boringerne 27.108, 27.109, 27.110 og 27.114 står udelukkende i saltvandsførende sand. De tilhørende punktprofiler*) viser tydeligt, hvorledes tilstedeværelsen af saltvand nedsætter sandlagenes specifike modstand.

De modstandsværdier, der er beregnet ud fra de geoelektriske måleresultater (tabel III), er gennemgående i ret god overensstemmelse med de værdier, der efter fig. 9, p. $51 \mathrm{kan}$ beregnes ud fra grundvandets saltholdighed. For de dybere liggende sandlags vedkommende er der dog nogen afvigelse. Ud fra fig. 9 kan modstanden for intervallet bor. $27.114(18,0-20,0 \mathrm{~m})$ således beregnes til ca. $10 \mathrm{OHMm}$, når der forudsættes en porøsitet på $30 \%$, medens modstanden ud fra de geoelektriske måleresultater er beregnet til $28 \mathrm{OHMm}$. Det bør dog bemærkes, at punktprofilkurvens form antyder en mulighed for, at laggrænsen ved $15,0 \mathrm{~m}$ kan ligge i større dybde, hvilket medfører, at uoverensstemmelsen mellem de to størrelser bliver noget mindre. Endvidere ses, at faldet i grundvandets saltholdighed i det nederste afsnit af bor. 27.109 ikke påvirker punktprofilkurvens forløb.

Ved profilerne svarende til boringerne 27.109 og 27.110 er modstanden i det saltvandsførende sand af samme størrelsesorden som de værdier, der tilskrives lerlagene i områderne med ferskvandsførende sandlag. For profilet svarende til bor. 27.114 er modstandsniveauet noget højere, hvilket må sættes i forbindelse med den forholdsvis lave saltholdighed i grundvandet.

Ler underlejret af saltvandsførende sand træffes i boringerne 26.454, 27.103107, 27.111, 27.116 og 27.117. Punktprofilkurvernes forløb varierer blandt andet med lerlagenes mægtighed og dybde samt med porevandets saltholdighed i henholdsvis ler og sand.

Ifølge beregningerne over lerfrie sandlags modstandsforhold (p. 51) må det antages, at sandet viser større modstand end leret, når grundvandets saltholdighed er væsentlig mindre end $2000 \mathrm{mg} \mathrm{Cl}-/ 1$, medens en større saltholdighed i grundvandet må medføre, at sandlagene udviser samme eller endog lavere modstand end lerlagene.

Punktprofilkurvernes forløb er i store træk i overensstemmelse med disse forhold, dog synes kurveforløbet $\mathrm{i}$ visse profiler, f. eks. 27.103 påvirket af nærliggende forekomster af ler eller mere saltholdigt grundvand.

For intervallerne $26.454(0,29-1,15 \mathrm{~m})$ og $27.116(2,4-8,0 \mathrm{~m}) \mathrm{kan}$ de forholdsvis

*) Der er ikke foretaget punktprofilopmåling svarende til bor. 27.108. 
lave modstandsværdier sættes i relation til de tilstedeværende lerlag. I de øvrige profiler er grundvandet så saltholdigt, at lerlagene ikke kan lokaliseres ud fra punktprofilkurverne.

\section{Sammenfattende vurdering af den geoelektriske kortlægning}

Da området som helhed karakteriseres ved stærkt varierende geologiske og hydrologiske forhold, vil horisontale variationer i jordlagenes og grundvandets sammensætning antagelig øve indflydelse på modstandsmålingerne til større dybde for en del punktprofilers vedkommende. Dette forhold medfører, at det bliver vanskeligt at bedømme, hvorledes afvigelsen mellem de geofysiske og de geologiske laggrænser varierer med lerlagenes lokale mægtighed og dybde.

I de dele af området, hvor der optræder ferskvandsførende sandlag, kan lerforekomsterne lokaliseres som intervaller med en forholdsvis lav specifik modstand, men bedømmelsen af lerlagenes mægtighed er behæftet med usikkerhed. Hvor der optræder saltholdigt grundvand med over ca. $2000 \mathrm{mg}$ $\mathrm{Cl}^{-} / 1$, er sandlagenes modstand derimod af en så ringe størrelsesorden, at lerlagene ikke kan påvises. Det kan således være vanskeligt at afgøre, i hvilken udstrækning lave modstandsværdier skyldes ler eller saltvandsførende sand. Følgende princip synes dog at være af almen gyldighed for området: hvor punktprofilkurven udviser et minimum, taler sandsynligheden for tilstedeværelse af lerforekomster; en med dybden aftagende modstand antyder derimod, at der optræder saltvandsførende sandlag, og det kan i disse tilfælde sjældent afgøres, om der optræder lerlag. Disse forhold afspejles iøvrigt også på resistivitetskortets kurveforløb ved henholdsvis $10 \mathrm{og} 20 \mathrm{~m}$ trenching (se fig. 6, p. 40, hvor $10 \mathrm{OHMm}$ kurverne er indtegnet). Ved Kristianshåb og $\mathrm{i}$ områderne omkring bor. 27.118 og 27.119, hvor lerlagene er underlejret af ferskvandsførende sandlag, medfører den forholdsvis høje modstand i jordlagene i boringernes nedre afsnit således, at $10 \mathrm{OHMm}$ kurven omskriver et større areal ved $10 \mathrm{~m}$ trenching end ved $20 \mathrm{~m}$ trenching. I kystområdet, hvor grundvandets saltholdighed som regel stiger med dybden, og jordlagenes modstand derfor ofte aftager med dybden, bliver følgen derimod, at $10 \mathrm{OHMm}$ kurven omslutter et større areal og når længere bort fra kysten ved $20 \mathrm{~m}$ end ved $10 \mathrm{~m}$ trenching.

Der er i denne forbindelse grund til at henlede opmærksomheden på, at de forskellige lertypers specifike modstand ifølge de geoelektriske måleresultater har vist sig at være stærkt varierende (se SORGENFREI, 1955, p. 78). Dette medfører en mulighed for, at ler i områder med saltholdigt grundvand i visse tilfælde kan udvise en tydeligt højere specifik modstand end sand som følge af, at saltholdigheden $\mathrm{i}$ de to sedimenttypers porevand ikke nødvendigvis er af samme størrelsesorden. En nærmere fastlæggelse af intervaller for saltholdigheden i sandlagenes porevand, for hvilke der kan forventes samme modstand i ler og sand, vil antagelig kunne foretages ud fra modstandsmålinger på intakte prøver af forskellige ler- og sandtyper. 


\section{SUMMARY}

\section{Introduction}

Since 1953 resistivity methods have been increasingly applied in Denmark in prospecting for water and-to a minor extend-for clay and gravel deposits.

The purpose of the present paper is to throw light upon some of the problems involved in the interpretation of resistivity measurements.

The material investigated originates from a prospecting survey for clay deposits carried out at the request of Aalborg Portland-Cement-Fabrik, Ltd., by the Geological Survey of Denmark. The surveyed area is shown on fig. 1, p. 8 .

\section{Laboratory Investigations}

Laboratory work included determination of carbonate content, salinity, and conductivity of suspensions of rock samples from a number of exploration wells. The determinations were made on material dried at $105^{\circ} \mathrm{C}$ after sorting out grains of gravel.

The carbonate content was determined by treatment of the sample with a measured volume of $0,5 \mathrm{n} \mathrm{HCl}$ followed by determination of the excess of acid by titration with $0,5 \mathrm{n} \mathrm{NaOH}$.

The determination of salinity was based on titration of the suspensions made for conductivity measurements with $0,0141 \mathrm{n} \mathrm{AgNO}_{3}$.

Conductivity of the suspensions was measured at $21^{\circ} \mathrm{C}$ after extraction for about 24 hours. The suspensions were made from $50 \mathrm{~g}$ samples and $250 \mathrm{ml} \mathrm{H}_{2} \mathrm{O}$. Resistivity is calculated from conductivity (resistivity as $\mathrm{OHMm}=10$ : conductivity as $\mathrm{mMHO}$ ).

Uncertainty of the determinations appears from table I, p. 12 and fig. 2, p. 13.

Analyses of water samples comprise the constituents reported in table II pp. $42-43 . \mathrm{Na}^{+}$and $\mathrm{K}^{+}$are determined by flame-photometry methods. $\mathrm{Na}^{+}+$ $\mathrm{K}^{+}$comprise values computed as difference between the sum of the determined anions and cations and reported in terms of equivalent amounts of $\mathrm{Na}^{+} \cdot \mathrm{Ca}^{++}$ and $\mathrm{Mg}^{++}$are determined by titration with ethylendiaminetetraacetic acid. The rest of the constituents are determined by standard methods of DANSK STANDARD, yet with some modifications for $\mathrm{PO}_{4}^{---}, \mathrm{Fe}^{++}$and $\mathrm{Mn}^{++}$. 


\section{The Sediments}

Lithological sections and results of the analyses are shown on plate Ia-b. All values are based on dried material. Samples of sand and White Chalk are average samples of sediments of $0,5 \mathrm{~m}$ intervals.

\section{Carbonate Content}

Samples of White Chalk generally contain $80-95 \% \mathrm{CaCO}_{3}$. Samples with a lower carbonate content are contaminated by sand, probably during the drilling operations.

The carbonate content of the Quaternary sediments is mainly due to reworked rocks of Upper Cretaceous age. The well-sorted sediments show some relation between carbonate content and grain size. Humic and weathered sediments are rather low in carbonate content. This is probably due to undersaturation of the interstitial water with respect to $\mathrm{CaCO}_{3}$, and in case of mud diluting of the minerogene fraction with organic material may be the explanation.

\section{Salinity}

The salinity of the dried samples of clay is supposed to be rather closely related to the salinity of the sediments in situ. Calculated salinities of the interstitial water of some clay deposits with a rather well known natural water content (30-35\% of dried material) are shown on plate Ia-b. Comparison of these values with salinity of the water samples shows that salinity of the interstitial water of the clay deposits and the adjacent sand deposits rarely are of the same order.

The salinity of the samples of sand and White Chalk has no relation to the salinity of the ground water (see fig. 3, p. 30) or the sediments in situ.

\section{Resistivity of the Suspensions}

The dependence of resistivity on salinity and rock type appears from plate $\mathrm{I} a-\mathrm{b}$ and fig. 4 , p. 31. In suspensions of sand and White Chalk the resistivity is mainly controlled by the salinity, while the resistivity of clay and mud suspensions is dependent on the salinity and the content of conductive solids like clay minerals and organic material.

The conductance of the clay fraction appears from fig. 5a-b, p. 32 . Fig. $5 \mathrm{a}$ is based on the curves of fig. 4 . Fig. $5 \mathrm{~b}$ shows the conductance of the clay fraction of a sample of boulder clay (calcium-clay) from well No. 26.456 $(11,0-11,5 \mathrm{~m}$.) and of sticky clay (sodium-clay) from well No. 27.105 (3,0$3,5 \mathrm{~m}$.).

The conductance of the clay fraction of the clay suspensions is assumed mainly to be related with size of the clay fraction and the nature of the adsorbed 
cations. The composition of the clay fraction has probably also some influence.

The conductance of the organic material is considered responsible for the low resistivity of the suspensions of humic sand and mud.

\section{Results of the Investigations Related to the Geology of the Area}

The geology of the area has been treated by A. JESSEN (1905 and 1936). The main features are the following.

The Pre-Quaternary bedrock consists of Senonian White Chalk. Interglacial deposits have not yet been encountered, and the Glacial deposits probably date from the latest glaciation. During the retreat of the ice the area between the Limfjord and Vester Hasing was covered by the Late-Glacial Sea (shore lines at 20-30 m. a. s. 1.). The Late-Glacial sediments include »Lower and Upper Saxicavasand « and "Yoldia clay«. During the Ancylus stage the area was uplifted above sea level. Later the Littorina Sea transgressed (shore lines at about $8 \mathrm{~m}$. a. s. 1.). The Post-Glacial marine sediments include sand, clay and mud. Subsequent uplift resulted in the present coastal plain.

The samples examined during the present study are mainly from Quaternary sediments. The Senonian White Chalk has only been encountered by four of the drilled wells at depths ranging from 11 to 22 meters (see plate Ia-b and fig. 6, p. 40). Subordinate deposits of boulder clay have been found in the north western part of the area. A large part of the sand deposits is supposed to be glaciofluvial meltwater sand. The sticky clay characterized by a carbonate content of about $30 \% \mathrm{CaCO}_{3}$ is referred to as Late-Glacial Yoldia clay. Calculated salinities of the interstitial water of these clays are shown on plate Ia-b. The figures may, however, not be identified with the salinity of the sea water in which the sediments were laid down. The primary salinity of the clays may have been somewhat altered after sedimentation since the clay deposits have been partly uplifted above sea level (during the Ancylus stage) and later covered by the Littorina Sea (concerning alteration of the primary salinity of some Post- and Late-Glacial clay deposits see V. Mik Kelsen, 1956 and R. W. Feyling-Hanssen, 1957). The best agreement between primary and recent salinity is assumed for the inner part of the clay deposits as displayed by well No. 27.113, where the calculated salinities are 11-13\%. The figures concerned are of the same order as found by B. KULLENBERG (1952) in varved clays from the southern Baltic. They are, however, a little lower than the figures for some marine Late-Glacial clay deposits in the Oslofjord area as assumed by R. W. Feyling-HAnssen (1957) on the basis of microfaunistic studies. Sediments from the Ancylus stage are represented by peat in wells No. 27.112, 27.115 and 27.116 and mud in well No. 27.117 (24,0-25,5 m.). Marine sediments from the Littorina stage including sand, clay or mud are found in a great majority of the wells. 


\section{The Ground Water}

Results of the water analyses are shown in table II pp. 42-43 and in the graph. of plate I $\mathrm{a}-\mathrm{b}$ and II.

The following water types were encountered.

1. Waters not modified by sulfate reduction or base-exchange reactions. This type includes fresh water and saline water with some permanent hardness.

2. Waters modified by sulfate reduction and softening base-exchange reactions. This type includes fresh water and saline water. A majority of the water samples contain $\mathrm{NaHCO}_{3}$, and $\mathrm{NH}_{4}{ }^{+}$frequently occurs. The softening base-exchange reactions may result from contact between the water and the marine argillaceous sediments of Holocene or Pleistocene age. In some cases the sulfate reduction may be caused by the humic sediments of Holocene age, in other cases it may probably indicate occurences of rather closed basins connected with the clay deposits. Concerning sulfate reduction and base-exchange reactions in Danish waters see H. ØDum and Wr. Christensen (1936).

3. Waters more or less modified by softening base-exchange reactions. This type mainly includes saline water. Waters of minor salinity have been modified to some extend by softening base-exchange reactions. With increasing salinity the composition of the water changes into that of sea water.

4. Waters somewhat modified by hardening base-exchange reactions. This type includes saline water rather rich in calcium, probably due to contact between salt water and calcium-clay. This type is only represented by one water sample, and it is not considered characteristic for the area.

The salinity of the ground water is assumed mainly to be due to contamination by sea water from the Limfjord, the sea water intrusion being related to hydrostatic head of the fresh water, permeability of the sediments and percolation of sea water from the surface during flood. Contamination by connate water of Pleistocene and Holocene age may probably occur to a minor extend.

As a whole the area is characterized by a complicated hydrological setting (see fig. 6, p. 40) which is related to the complex geology of the area. It also shows that one or a few water samples from an area may not be representative.

\section{The Resistivity Survey}

\section{Resistivity of the Sediments}

The electrical properties of a rock may be characterized by the formation factor $F=\rho_{\mathrm{o}} / \rho_{\mathrm{v}}$ where $\rho_{\mathrm{o}}$ is the resistivity of the rock when saturated with water having a resistivity of $\rho_{\mathrm{v}}$. For a given rock without conductive solids, e. g. clay minerals, the formation factor is a constant related to other physical 
properties like porosity and permeability. Resistivity of argillaceous rocks is affected by the clay fraction too, and consequently the formation factor is not a constant but it varies with resistivity of the interstitial water. Concerning the resistivity of rocks reference is made to e. g. C. A. Heiland (1951) and J. W. Amyx, D. M. Bass and R. L. Whiting (1960).

Clay. As mentioned above the clay minerals may act as conductors and contribute to the conductivity of an argillaceous rock. On the basis of resistivity measurements on intact samples PATNODE and WyLLIE (1950) considered the conductance of the clay fraction of a given sample as a constant. HiLL and Milburn (1956) stated however, that the conductance of the clay fraction is changing with salinity of the interstitial water, being related to the sample cation-exchange capacity per unit pore volume. The latter opinion is in best agreement with the fact that clay may be considered a dynamic system whose electro-chemical and physical properties are changing with the chemical character of the fluid phase (see RosENQvisT, 1955).

Calculation of the conductance of the clay fraction cannot be made from the present material, the values calculated from measurements on the suspensions (pp. 31-32) being only true values for the particular conditions under which the measurements were made. However, some relation between resistivity of the different clays and the electrical properties of the corresponding suspensions may be expected. On that assumption the following general features concerning resistivity of the clays may be deduced:

For a given composition of the interstitial water the resistivity of clay is lower than that of sand, partly due to a higher water content and partly due to conductance of the clay minerals. The resistivity of a rock may vary with size and composition of the clay fraction and with the content of other conductive solids. For the clays here considered the resistivity is supposed to decrease in the following order: boulder clay, weathered clay, sticky clay, humic clay and mud. The resistivity of a given clay may, moreover, vary with the salinity of the interstitial water, the relation between the two factors being rather complicated since both resistivity of the fluid phase and that of the solid phase may be supposed to change with salinity. Further investigation is required before the relative effect of the fluid and the solid phase on resistivity of the clays here examined can be determined.

Sand. The resistivity of sand without conductive solids may be calculated from porosity and resistivity of the interstitial water. A few determinations of the porosity of closely packed samples from the intervals well No. 26.106 $(4,5-6,0 \mathrm{~m}$.) $(10,0-11,5 \mathrm{~m}$.) and $27.107(8,5-10,0 \mathrm{~m}$.) have given values ranging from 27 to $32 \%$. It may be supposed that the porosity of the sand deposits as a whole is on the order of $25-45 \%$. Knowledge of the resistivity of the interstitial water is based on conductivity measurements on salt solutions, the composition of which agree with some of the water analyses. In fig. 9, p. 51, the 
calculated resistivities of sand deposits are shown. The calculations are derived from the curves in fig. 7, p. 49 and fig. 8, p. 50.

From fig. 9, it appears that the resistivity of the sand deposits decreases with increasing salinity of the interstitial water. In this connection it should be mentioned, that field measurements of the resistivity of boulder clay show figures on the order of $30-40 \mathrm{OHMm}$ while the resistivity of the Late-Glacial Yoldia clay is less than $10 \mathrm{OHMm}$. Our knowledge of the salinity of the ground water in the area is sufficient to allow the conclusion, that the resistivity of the sand deposits of part of the area may be of the same order or still lower than that of the clay deposits due to the salinity of the interstitial water.

\section{The Resistivity Sounding}

Theory of the geoelectrical method used (after WENNER) and results of some previous geoelectrical surveys have been published by TH. SorgenfreI (1955).

The present survey was a prospecting survey for clay deposits. Resistivity mapping (trenching) was made with electrode spacings of 10 and 20 meters. The major part of the subsequent resistivity soundings were made in areas surrounded by the $10 \mathrm{OHMm}$ curves. The wells which later were drilled showed that clay deposits or salt water-bearing sand occure in these areas of low resistivity (see fig. 6, p. 40).

The apparent resistivity curves are shown on plate $\mathrm{I} a-b$, the values concerning depths greater than the corresponding wells being not reported. The resistivities calculated on the basis of these curves (in logarithmic scale) are listed in table III, p. 53.

Sediments above the ground water table generally show high resistivities; the values vary with rock type and are supposed to be mainly controlled by the water content of the sediments.

Below the ground water table the resistivity profile is related to geology and particularly to ground water properties.

The following geohydrological settings are encountered in the area.

Clay underlain by fresh water-bearing sand is found in the wells No. 26.455, $26.456,27.112,27.113,27.115,27.118$ and 27.119. The apparent resistivity curves show a characteristical minimum, the resistivity being largely dependent on the salinity of the clay. Intervals with a calculated resistivity below $10 \mathrm{OHMm}$ are assumed mainly to be related to clay deposits. There are some disagreements however, between the geophysical and the geological boundaries, probably due to horizontal and vertical discontinuities in resistivity related to the complicated geological and hydrological pattern. The low resistivities in 26.456 may thus be supposed due to adjacent clay deposits.

Salt water-bearing sand (wells No. 27.108, 27.109, 27.110 and 27.114). From the resistivity curves it appears how the resistivity of the sand deposits de- 
creases with increasing salinity of the ground water. Resistivities calculated from the field measurements agree rather well with resistivities calculated from fig. 9, p. 51. There are, however, some disagreements regarding the deep lying intervals (see 27.109 and 27.114). The resistivities of the sand sections in wells No. 27.109 and 27.110 are of the same order as those of clay deposits as described above. The resistivities at 27.114 are somewhat higher.

Clay underlain by salt water-bearing sand is found in the wells No. 26.454, 27.103-107, 27.111, 27.116 and 27.117. The apparent resistivity curves change with thickness and depth of the clay deposits and with the salinity of the interstitial water of clay and sand respectively. From fig. 9 it may be deduced that only with a salinity of the ground water below about $2000 \mathrm{mg} \mathrm{Cl}^{-} / 1$ the resistivity of sand is higher than that of the sticky clay. The resistivity profiles as a whole agree with this assumption, the resistivities apparently being somewhat affected by horizontal discontinuities (see 27.103). With a few exceptions $(26.454(0,29-1,15 \mathrm{~m}$.) and $27.116(2,4-8,0 \mathrm{~m}$.) ) the salinity of the ground water is so high that location of the clay deposits cannot be made on the basis of the resistivity profiles.

\section{General conclusion}

The surveyed area is characterized by a varied geological and hydrological setting. The resistivity measurements may consequently be rather much influenced by horizontal discontinuities resulting in disagreements between the geophysical and the geological boundaries.

In areas with fresh water-bearing sand the clay deposits can be localized as intervals with low resistivities. Salt ground water decreases the resistivity, and in the case of salinities being above atout $2000 \mathrm{mg} \mathrm{Cl}^{-} / 1$ the resistivity of the sand deposits is so low that the deposits of sticky clay cannot be localized on the basis of geoelectrical field measurements. It may thus be difficult to decide, whether areas of low resistivities may be due to clay or to salt water-bearing sand. The following rule is of general validity concerning the present resistivity measurements: a resistivity minimum may be related to clay deposits while resistivities constantly decreasing with depth suggest occurrence of salt water. In the latter case it cannot be decided whether clay deposits occur in the subsurface.

In this connection attention may be drawn to the possibility that clay c'eposits may show higher resistivities than adjacent sand deposits with salt water if the interstitial water of the sand is of a higher salinity than that of the clay. Further investigations on this matter should be based on resistivity measurements on intact samples of different clays and sands. 


\section{LITTERATUR}

D.G.U. = Danmarks Geologiske Undersøgelses skrifter. - København.

D.G.F. = Meddelelser fra Dansk Geologisk Forening. - København.

Amyx, J. W., Bass, D. M. and Whiting, R. L., 1960: Petroleum Reservoir Engineering. Physical Properties. - New York.

AslynG, H. C., 1955: Marskjordens fysiske og kemiske tilstand. - Tidsskr. f. Planteavl. Bd. 59, H. 2, pp. 328-344. - København.

Christensen, Wr., 1962: Betragtninger over den geokemiske udvikling i de øvre jordlag $\mathrm{i}$ Danmark. Den sure Front. - D.G.F. Bd. 15, H. 1, pp. 112-122.

Engelhardt, W. v., 1960: Der Porenraum der Sedimente. - Berlin.

FEYLING-HANSSEN, R. W., 1957: Micropaleontology applied to soil mechanics in Norway.Norw. Geotechn. Inst. Publ. No. 20. - Oslo.

Grim, R. E., 1953: Clay Mineralogy. - New York.

GripenberG, S., 1934: A Study of the Sediments of the North Baltic and adjoining Seas.Havsforskningsinstitutets Skrift, No. 96. - Helsingfors.

Heiland, C. A., 1951: Geophysical Exploration. - New York.

HeM, J. D., 1959: Study and Interpretation of the Chemical Characteristics of Natural Water. - Geological Survey Water-Supply Paper 1473. - Washington.

Hill, H. J. and Milburn, J. D., 1956: Effect of Clay and Water Salinity on Electrochemical Behavior of Reservoir Rocks. - Petroleum Transactions, Aime. Vol. 207. - Dallas, Texas.

Jensen, S. Tovborg, 1955: Om Nordsømarsken og dens landøkonomiske udnyttelse. Tidsskr. f. Planteavl. Bd. 59, H. 2, pp. 291-327. - København.

JESSEN, A., 1905: Beskrivelse til Geologisk Kort over Danmark. Kortbladene Aalborg og Nibe (nordlige Del). - D.G.U. I. Rk. Nr. 10.

- 1936: Vendsyssels Geologi. - D.G.U. V. Rk. Nr. 2.

KullenberG, B., 1952: On the salinity of the water contained in marine sediments. Göteborgs Kungl. Vetenskaps- och Vitterhets-samhälles Handlingar. Sjätte føljden. Ser. B. Band 6, N:o 6. - Göteborg.

- 1954: On the presence of sea water in the Baltic ice-lake. - Tellus. Vol. 6, No. 3, pp. 221-228. - Stockholm.

Marshall, C. E., 1949: The Colloid Chemistry of the Silicate Minerals. - Agronomy. Vol. 1. - New York.

MikKelsen, V. M., 1956: The salinity of the water contained in brackish-water sediments compared with the content of diatoms and other organisms in the same sediments. D.G.F. Bd. 13, H. 2, pp. 104-111.

Milthers, V., 1903: Grundvand og vandførende Lag i Danmark, særlig med Henblik på Forsyningen af Brønde. - D.G.U. III. Rk. Nr. 4.

Patnode, H. W. and Wyllie, M. R. J., 1950: The Presence of Conductive Solids in Reservoir Rocks as a Factor in Electric Log Interpretation. - Petroleum Transactions, Aime. Vol. 189. - Dallas, Texas.

Rosenqvist, I. Th., 1955: Investigations in the clay-electrolyte-water system. - Norw. Geotechn. Inst. Publ. No. 9. - Oslo.

Sorgenfrei, TH., 1955: Geoelektriske Undersøgelser i Danmark og Skåne 1953. - D.G.U. III. Rk. Nr. 32.

Söderblom, R., 1957: Some Investigations Concerning Salt in Clay. - Proc. 4. Int. Conf. Soil Mech. a. Found. Engen. Vol. 1. pp. 111-115. - London.

Ødum, H. og Christensen, Wr., 1936: Danske Grundvandstyper og deres geologiske Optræden. - D.G.U. III. Rk. Nr. 26. 
Denne bog er sat med 10-punkt Monotype Times og trykt i 1500 eksemplarer på Andelsbogtrykkeriet i Odense. Papir: Ekstraglittet 605, $125 \mathrm{~g}$, fra A/S De forenede Papirfabrikker. 


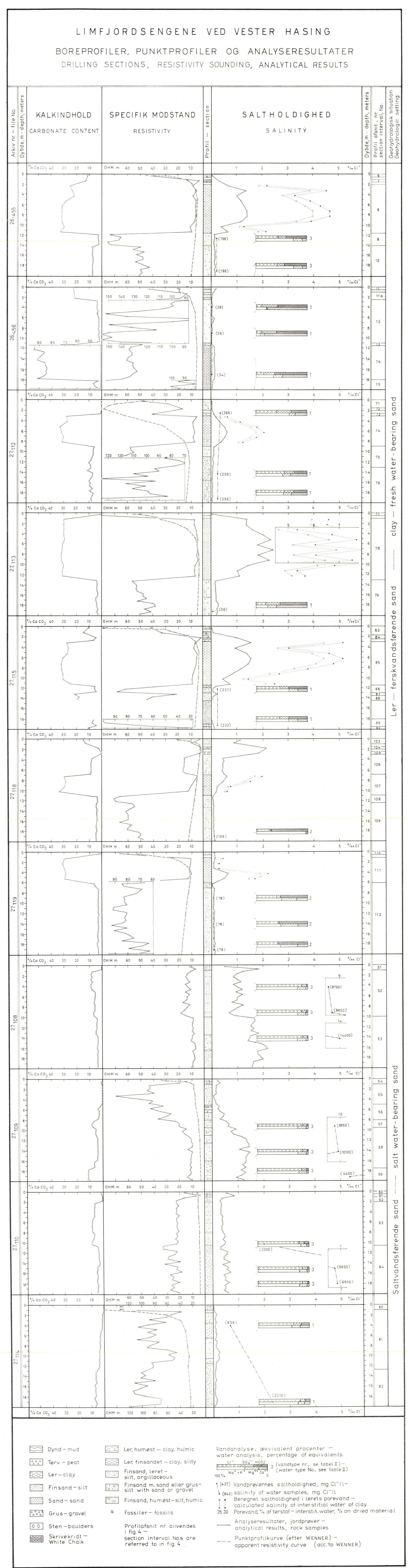




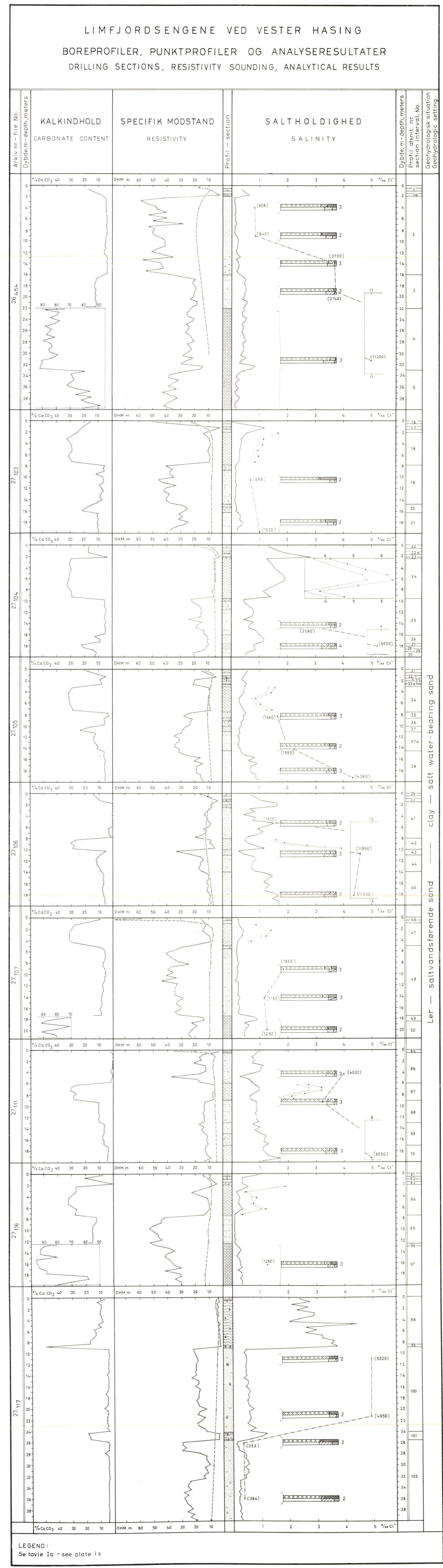


V A N D A N A L Y SER - WATER A N A L Y S E

EKVIVALENT PROCENTER - PERCENTAgE OF EquiVAlentS
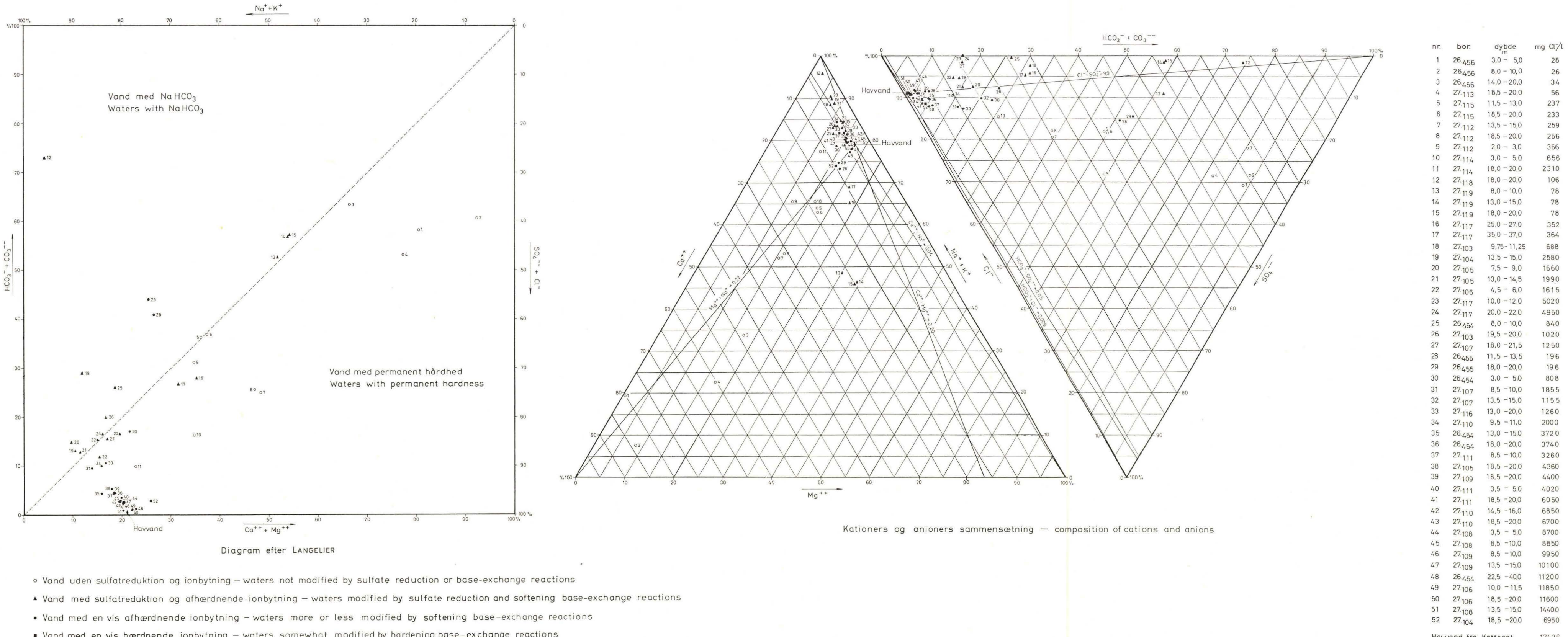

- Vand uden sulfatreduktion og ionbytning - waters not modified by sulfate reduction or base-exchange reactions

- Vand med en vis afherdnende ionbytning - waters more or less modified by softening base-exchange reactions

Kationers og anioners sammensetning - composition of cations and anions

- Vand med en vis herdhende ionbytning - waters somewhat modified by hardening base-exchange reactions

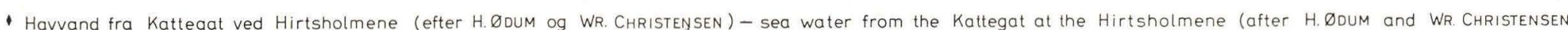

Vandanalyse $\mathrm{nr}$. (tabel II) - water anatysis No. (table II) 